\title{
Measurement Properties of Patient-Reported Outcome Measures for Diabetes: Systematic Review
}

Priscilla Jia Ling Wee ${ }^{1 *}$, LLB; Yu Heng Kwan ${ }^{2,3^{*}}$, BSc, MD, PhD; Dionne Hui Fang Loh ${ }^{4}$, BEng; Jie Kie Phang ${ }^{5}$, BSc; Troy H Puar ${ }^{6}$, MBBS, MRCP; Truls Østbye ${ }^{2}$, MD, MPH, PhD; Julian Thumboo ${ }^{2,5,7}$, MBBS, MMed, MRCP; Sungwon Yoon ${ }^{2}$, MPH, PhD; Lian Leng Low ${ }^{4,8,9}$, MBBS, MMed, MCI

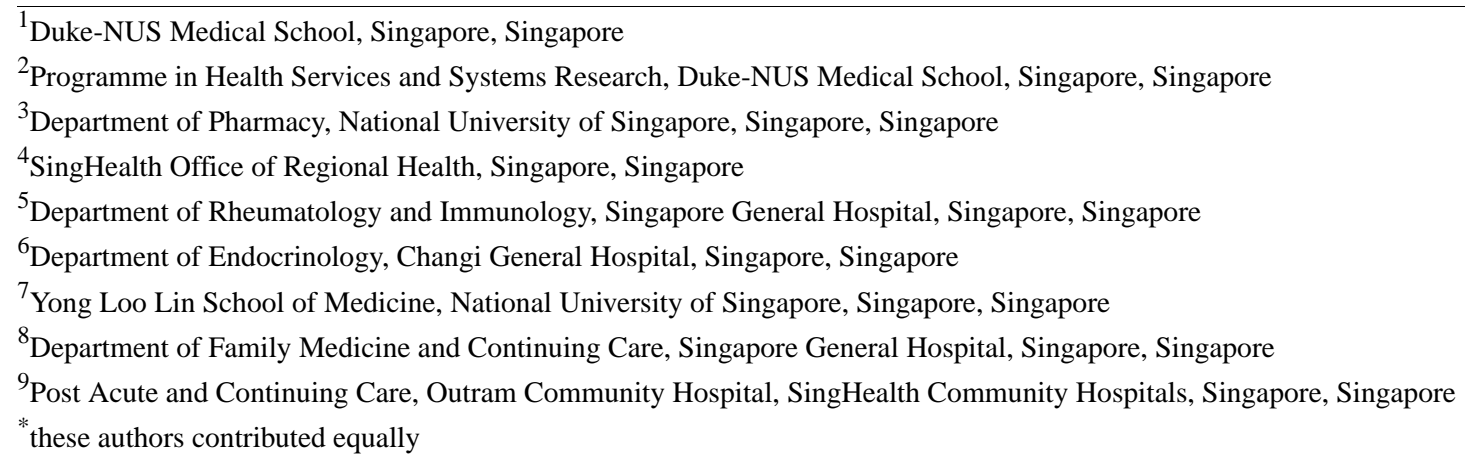

\section{Corresponding Author:}

Yu Heng Kwan, BSc, MD, PhD

Programme in Health Services and Systems Research

Duke-NUS Medical School

8 College Road

Singapore, 169857

Singapore

Phone: 6590231226

Fax: 6565348632

Email:phakyh@nus.edu.sg

\section{Abstract}

Background: The management of diabetes is complex. There is growing recognition of the use of patient-reported outcome measures (PROMs) as a standardized method of obtaining an outlook on patients' functional status and well-being. However, no systematic reviews have summarized the studies that investigate the measurement properties of diabetes PROMs.

Objective: Our aims were to conduct a systematic review of studies investigating the measurement properties of diabetes PROMs by evaluating the methodological quality and overall level of evidence of these PROMs and to categorize them based on the outcome measures assessed.

Methods: This study was guided by the PRISMA (Preferred Reporting Items for Systematic Review and Meta-Analysis) guidelines. Relevant articles were retrieved from the Embase, PubMed, and PsychINFO databases. The PROMs were evaluated with the COSMIN (COnsensus-based Standards for the selection of health Measurement Instruments) guidelines.

Results: A total of 363 articles evaluating the measurement properties of PROMs for diabetes in the adult population were identified, of which 238 unique PROMs from 248 studies reported in 209 articles were validated in the type 2 diabetes population. PROMs with at least a moderate level of evidence for $\geq 5$ of 9 measurement properties include the Chinese version of the Personal Diabetes Questionnaire (C-PDQ), Diabetes Self-Management Instrument Short Form (DSMI-20), and Insulin Treatment Appraisal Scale in Hong Kong primary care patients (C-ITAS-HK), of which the C-PDQ has a "sufficient $(+)$ )" rating for $>4$ measurement properties. A total of 43 PROMs meet the COSMIN guidelines for recommendation for use.

Conclusions: This study identified and synthesized evidence for the measurement properties of 238 unique PROMs for patients with type 2 diabetes and categorized the PROMs according to their outcome measures. These findings may assist clinicians and researchers in selecting appropriate high-quality PROMs for clinical practice and research. 
Trial Registration: PROSPERO International Prospective Register of Systematic Reviews CRD42020180978; https://www.crd.york.ac.uk/prospero/display_record.php?ID=CRD42020180978.

(J Med Internet Res 2021;23(8):e25002) doi: 10.2196/25002

\section{KEYWORDS}

systematic review; measurement properties; patient-reported outcome measures; methodological quality; level of evidence; PROMs; patient reported outcome; diabetes

\section{Introduction}

Diabetes is a serious and common chronic condition that affects approximately 425 million people worldwide between the ages of 20 and 79 years [1]. The management of diabetes is complex and multifaceted, as the disease is associated with various complications and imposes significant psychological and emotional burdens on the individual [2]. Successful diabetes care requires a systematic approach to support patients' behavior change efforts, including healthy lifestyle choices, self-management, and identification of self-management problems [2]. Hence, clinical decisions made in the management of diabetes should be patient-centered, as this approach can help clinical providers identify barriers to adherence as well as motivations for self-care [2].

Recognition is growing of the usefulness of patient-reported outcome measures (PROMs) in patient-centered care and clinical decision-making [3]. PROMs are direct reports of a patient's health status and well-being from their own perspective [4]. By providing a platform for patients to convey their disease experience, and by serving as a screening tool for underlying mental and functional problems, PROMs can bridge the gap between clinical concerns and patient perspectives, providing a more holistic assessment for enhancing diabetes care [4].

To fill this need, a considerable number of different PROMs for patients with diabetes in the adult population ( $>18$ years of age) have been developed and revised over the last two decades. Examples include the 39-item Diabetes-39 (measuring quality of life of people with diabetes) [5] and the 20-item Problem Areas in Diabetes (PAID) Scale (measuring emotional functioning in diabetes) [6], which has since been revised to a short form 5-item scale (ie, the PAID-5 [7]). The large number of available PROMs creates challenges for clinicians or researchers to select the most appropriate high-quality PROM for their specific needs. To date, no systematic review has summarized PROMs for diabetes, whether for diabetes in general or for subpopulations of patients with diabetes (eg, patients with type 2 diabetes), nor has a review consolidated the revisions made to existing PROMs for diabetes.

Moreover, existing systematic reviews have focused on the psychometric properties of only certain categories of diabetes PROMs (eg, PROMs evaluating only health-related quality of life measures [8], PROMs for diabetes self-care [9], or PROMs in patients with diabetes associated with foot and ankle pathologies [10]) or the use of PROMs/association of PROMs with diabetes and its complications [11], even though such PROMs may be validated and applicable to a wider population of diabetes patients; for example, the Mexican version of the
Diabetes Foot-Care Behavior Scale was validated in a population of patients with type 2 diabetes and not limited to patients with foot and ankle pathologies [12].

Therefore, we aimed to conduct a systematic literature review to identify studies investigating the measurement properties of PROMs validated in the population of patients with diabetes and evaluate the methodological quality and level of evidence relating to these measurement properties of PROMs. In addition, we aimed to categorize the PROMs by the type of outcome measure. This paper contains the psychometric results of the PROMs identified for patients with type 2 diabetes, and it is part of a series of papers to be published that will contain the results of the PROMs validated for (1) patients with type 1 diabetes; (2) patients with either type 1 or type 2 diabetes; and (3) patients with diabetes associated with complications such as peripheral neuropathy, retinopathy, or foot and ankle pathologies.

\section{Methods}

\section{Review}

This systematic review was guided by the PRISMA (Preferred Reporting Items for Systematic Review and Meta-Analyses) statement [13]. The measurement properties of each PROM were evaluated using the COSMIN (COnsensus-based Standards for the selection of health Measurement INstruments) Risk of Bias checklist [14]. The COSMIN evaluates PROM development and the following 9 measurement properties: content validity, structural validity, internal consistency, cross-cultural validity/measurement invariance, test-retest reliability, measurement error, criterion validity, hypotheses testing for construct validity, and responsiveness [14,15]. The results were used to determine the overall evidence of each PROM [16]. This systematic review has been submitted for registration on Prospero and registered on the Open Science Framework [17].

\section{Search Strategy}

The PubMed, Embase, and PsychINFO (Ovid) databases were searched for any articles published on or before March 31, 2020. A search strategy (Tables S1-S3, Multimedia Appendix 1) of three components was used as follows [18]: disease terms (diabetes and associated terms), construct of interest (PROMs and associated variations of this term), and measurement properties (as defined under the COSMIN criteria). Where available, the sensitivity of the searches was enhanced using search filters developed by Terwee et al [19] and the PROM Group, University of Oxford [20]. The search records were downloaded into Endnote X9 (Clarivate Analytics), and any duplicates were removed. 


\section{Article Selection}

Two reviewers (PWJL and DHFL) independently screened all titles and abstracts, and a third reviewer (YHK) was consulted to make a final decision when any disagreement arose between the two reviewers as to the relevance of the articles based on the inclusion and exclusion criteria. For articles that were potentially relevant, the full-text articles were independently reviewed by the same two reviewers for inclusion and exclusion.

We included full-text original publications in English that validated PROMs for patients with diabetes mellitus and evaluated the PROMs for at least one of the nine measurement properties listed in the COSMIN guidelines. The COSMIN guidelines evaluate PROM development using the following nine measurement properties: content validity [21], structural validity, internal consistency, cross-cultural validity/measurement invariance, test-retest reliability, measurement error, criterion validity, hypotheses testing for construct validity, and responsiveness. Their definitions are presented by Mokkink et al [22].

We excluded conference abstracts and studies that focused on measurement development or that included PROMs completed by proxy or by patients $\leq 18$ years of age. These exclusions were not used to construct the search strategy to avoid the omission of relevant studies. If only part of the study population consisted of PROMs directly reported by patients $>18$ years of age with diabetes, the articles were included if the results were reported separately for this group of patients. The type of study (eg, randomized controlled trial, cross-sectional study, cohort study, and registry-based study) was not part of our exclusion criteria to assess the measurement properties to ensure that this systematic literature review would be able to provide a comprehensive overview of the measurement properties of all types of PROMs.

\section{Data Extraction}

Two reviewers (PWJL and DHFL) extracted the following data (where available) from the articles:

1. General characteristics of the study populations: sample size, age, gender, and country where the study was conducted

2. Disease characteristics of the study population: disease studied and duration of illness
3. Characteristics of the PROMs: language version used, domains assessed, number of domains and items, and response scale

\section{Assessment of Methodological Quality}

Two reviewers (PWJL and DHFL) independently evaluated all relevant articles for methodological quality using the COSMIN Risk of Bias checklist [14], and a third reviewer (YHK) resolved any disagreement. Each measurement property was assessed based on a 4-point scale: inadequate, doubtful, adequate, or very good $[14,15]$. The item with the worst rating under each measurement property would determine the overall rating for the specific measurement property [23]. The assessed PROMs were then categorized according to their outcome measures.

\section{Assessment of Quality of Measurement Properties}

The quality of measurement properties of each PROM was assessed using the quality criteria described by Terwee et al [16]. First, the measurement properties to be evaluated were identified. Next, according to the results from the study of each measurement property, a "positive (+)," "indeterminate (?)," or "negative (-)" rating was assigned [16].

\section{Evidence Synthesis}

For each PROM, an evidence synthesis across all studies was conducted. First, we determined whether each measurement property for a PROM had overall "sufficient (+)," "insufficient (-)," "inconsistent ( \pm )," or "indeterminate (?)" evidence. Second, we graded the quality of evidence for each measurement property of the PROM as high, moderate, low, or very low based on the guidelines from the modified Grading of Recommendations Assessment, Development and Evaluation (GRADE) approach for systematic reviews of clinical trials $[15,24]$.

\section{Results}

\section{Search Results}

A total of 107,925 articles were obtained from the database search (Figure 1), of which 2831 duplicates were excluded. A review of the titles and abstracts excluded 104,392 articles. Then, after a full-text review, 339 articles were excluded for the reasons provided in Figure 1, resulting in 363 relevant articles. 
Figure 1. Flow chart of the systematic literature review. DM: diabetes mellitus; PROM: patient-reported outcome measure.

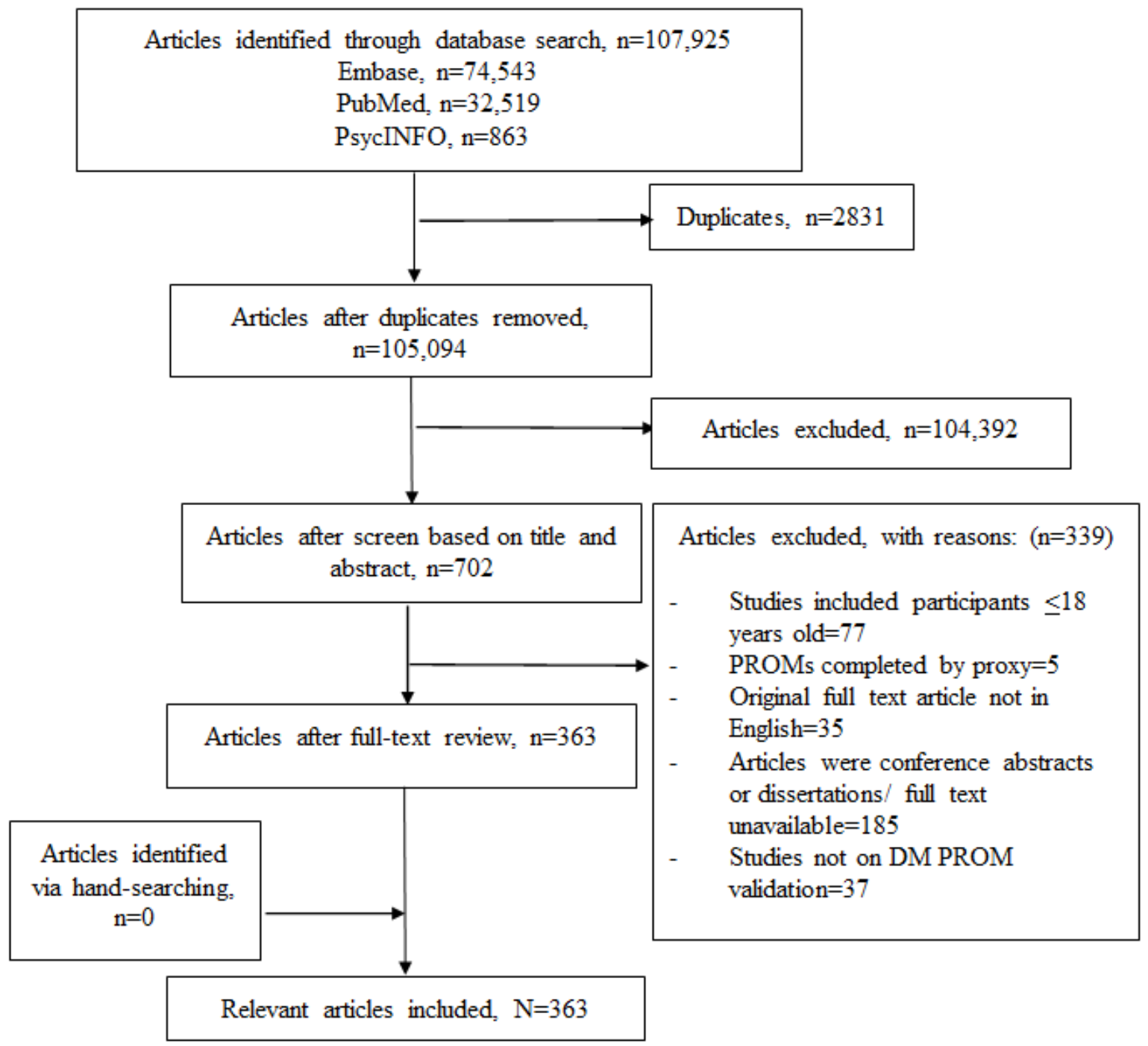

Out of the 363 relevant articles, 209 articles reporting on 248 studies validated PROMs for patients with type 2 diabetes, which are the focus of the subsequent analysis in this paper. A breakdown of the 363 relevant articles identified by patient population is provided in Table 1. The results of studies assessing other diabetes subpopulations will be published elsewhere.

Out of the remaining 209 articles reporting on studies that validated PROMs for patients with type 2 diabetes, 238 unique PROMs in 35 languages from 53 countries were identified (Table 2).

Table 1. Breakdown of relevant articles by patient population $(\mathrm{N}=363)$.

\begin{tabular}{ll}
\hline Patient population & Articles, $\mathrm{n}(\%)$ \\
\hline Type 2 diabetes & $209(57.6)$ \\
Type 1 diabetes & $16(4.4)$ \\
Type 1 or Type 2 diabetes $^{\mathrm{a}}$ & $119(32.9)$ \\
Diabetes with complications & $19(5.2)$ \\
\hline
\end{tabular}

${ }^{\mathrm{a}}$ Includes articles that did not differentiate between types of diabetes. Attempts were made to contact the authors for clarification. 
Table 2. Characteristics of the included articles.

\begin{tabular}{|c|c|}
\hline General characteristics & Value \\
\hline Unique PROMs ${ }^{\mathrm{a}}$ identified, $\mathrm{n}$ & 238 \\
\hline Unique countries identified, $\mathrm{n}$ & $53^{\mathrm{b}}$ \\
\hline Unique languages identified, $\mathrm{n}$ & $35^{\mathrm{c}}$ \\
\hline \multicolumn{2}{|l|}{ Sample size ${ }^{d}$ n $(\%)$} \\
\hline$<30$ & $6(2.42)$ \\
\hline $30-49$ & $6(2.42)$ \\
\hline $50-99$ & $24(9.68)$ \\
\hline$>100$ & $203(81.85)$ \\
\hline \multicolumn{2}{|l|}{ Mean age $^{d}$ (years), $n(\%)$} \\
\hline $30-39$ & $3(1.21)$ \\
\hline $40-49$ & $10(4.03)$ \\
\hline $50-59$ & $108(43.55)$ \\
\hline $60-69$ & $80(32.26)$ \\
\hline$\geq 70$ & $11(4.44)$ \\
\hline \multicolumn{2}{|l|}{ Proportion of males, ${ }^{e}$ n (\%) } \\
\hline$<0.5$ & $114(45.97)$ \\
\hline $0.5<x<0.6$ & $83(33.47)$ \\
\hline $0.6<x<0.7$ & $25(10.08)$ \\
\hline $0.7<x<0.8$ & $3(1.21)$ \\
\hline $0.8<x<0.9$ & $2(0.81)$ \\
\hline \multicolumn{2}{|c|}{ Disease characteristics: disease duration (years), ${ }^{e} n(\%)$} \\
\hline $0<$ mean disease duration $<10$ & $73(29.44)$ \\
\hline $10<$ mean disease duration $<20$ & $67(27.02)$ \\
\hline $20<$ mean disease duration $<30$ & $1(0.40)$ \\
\hline
\end{tabular}

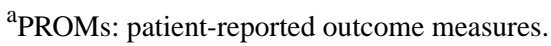

${ }^{\mathrm{b}}$ Some countries were not reported.

${ }^{\mathrm{c}}$ Some languages were not reported.

${ }^{\mathrm{d}}$ Inclusive of multiple studies reported on the same sample.

${ }^{\mathrm{e}}$ Some values were reported as median and range or were not reported.

\section{Characteristics of the PROMs}

The characteristics of the identified PROMs are presented in Table S4 in Multimedia Appendix 1. A majority of the PROMs studied were in English (27.82\%), and all PROMs identified were self-administered questionnaires.

\section{Categories of PROMs}

The 238 unique PROMs identified are categorized in Table 3. Based on the intended outcome measurements as described by the authors of the respective validation studies, the PROMs can be broadly categorized into three groups: first, general impact on quality of life questionnaires (eg, the World Health Organization Quality of Life questionnaire [WHOQOL-100] and the EuroQol 5-Dimension [EQ-5D]) (24/238,10.1\%); second, questionnaires measuring diabetes-specific impacts on quality of life (eg, the 19-item Audit of Diabetes-Dependent Quality of Life [ADDQoL-19]) (42/238,17.6\%), and third, questionnaires measuring specific aspects of dealing with diabetes (eg, PAID, which measures psychological impact, or the Diabetes Treatment Satisfaction Questionnaire [DTSQ], which measures satisfaction with diabetes treatment) $(172 / 238,72.3 \%)$. The majority of the PROMs fell into the third category, and they could be further classified into as follows: general psychosocial impact (eg, social/psychological/emotional well-being of patients with diabetes), diabetes-related depression, diabetes-related distress, self-efficacy (eg, patients' belief in their capability to organize and execute the course of action required to deal with their disease), self-management (eg, the range of activities patients must engage in on a regular basis to manage their diabetes), impact of empowerment tools (eg, the level of empowerment developed by patients as a result 
of educational interventions), health-promoting lifestyle behaviors (eg, in terms of physical activity or stress management), health beliefs (eg, perceived benefits of treatment), knowledge/competence, treatment experience (eg, the level of satisfaction with treatment), treatment compliance, symptoms

hypoglycemia and patients'

experiences/perceptions on this), nutrition and physical activity (eg, patients' perceptions on diet and exercise), sleep, support (eg, patients' perspectives on the availability of support for diabetes), attitude/coping with diabetes, obstacles and problem-solving, health perception (eg, patients' perspectives on their illness/diabetes-related health satisfaction). 
Table 3. Patient-reported outcome measures (PROMs) organized by category.

\begin{tabular}{ll}
\hline Category & Description \\
\hline $\begin{array}{l}\text { General impact on } \\
\text { quality of life }\end{array}$ & $\begin{array}{l}\text { Generic PROMs that are evaluated within the population } \\
\text { of patients with type } 2 \text { diabetes. These PROMs assess } \\
\text { the impact of chronic illness in terms of impact on quality } \\
\text { of life. }\end{array}$ \\
- $\begin{array}{l}\text { Examples of domains assessed include physical health, } \\
\text { psychological state, social relationships and environment, } \\
\text { mobility, self-care, usual activities, pain/discomfort, and } \\
\text { anxiety/depression. }\end{array}$
\end{tabular}

$\mathrm{PROMs}^{\mathrm{a}}$

WHOQOL-100 ${ }^{\mathrm{b}}$ [25]; WHOQOL-BREF ${ }^{\mathrm{c}}$ [26]; WHOQOLBREF (Malayalam version) [27]; WHOQOL-BREF 26 (Persian version) [28]; WHOQOL-BREF (Amharic version) [29]; RAND-12 ${ }^{\mathrm{d}}$ [30]; HSQ 2.0 ${ }^{\mathrm{e}}$ (Spanish version) [31]; HUI2 ${ }^{\mathrm{f}}$ [30]; HUI3 ${ }^{\mathrm{g}}$ [30,32]; EQ-5D ${ }^{\mathrm{h}}$ [33], [34]; EQ-5D-5L ${ }^{\mathrm{i}}$ [35-37]; EQ-5D-3L ${ }^{j}$ [38]; EQ-5D-3L (Finnish version) [38]; EQ-5D3L (German version) [38]; EQ-5D-3L (Greek version) [38]; EQ-5D-3L (Dutch version) [38]; EQ-5D-3L (Spanish version) [38]; EQ-5D-5L (Brunei-Malay version) [39]; PACIC ${ }^{\mathrm{k}}$ [40,41]; Short-version PACIC [42]; Modified-PACIC [43]; PACIC (Malay version) [44]; SF-36 ${ }^{1}$ [45]; SF-12v2 ${ }^{\mathrm{m}}$ [46]

Diabetes-specific impact on quality of life
PROMs that assess the impact of diabetes on quality of life, such as impact on physical function, psychological well-being and social well-being.

- Examples of domains assessed include physical function, symptoms, psychological well-being, self-care management, social well-being, global judgments of health, and satisfaction with care and flexibility of treatment.
General psychosocial impact

Diabetes-related depression

Diabetes-related distress

Self-efficacy
PROMs that assess the social/psychological/emotional well-being of patients with diabetes.

- Examples of domains assessed include anxiety, depressed mood, positive well-being, self-control, general health, and validity.

- $\quad$ PROMs that screen for depression in patients with diabetes/monitor the presence of depressive symptoms in patients with diabetes.

- Examples of domains assessed include depressed affect, somatic symptoms, positive affect, and interpersonal problems.

- PROMs that screen for diabetes-related emotional distress.

- Examples of domains assessed include emotional burden, physician-related distress, regimen-related distress, and interpersonal distress.

- $\quad$ PROMs that assess the level of self-efficacy (ie, people's belief in their capability to organize and execute the courses of action required to deal with prospective situations [107]) of patients with type 2 diabetes, whether in general or in dealing with specific aspects of diabetes (eg, in taking medication [108]).

- Examples of domains assessed include performing activities which are essential for the treatment of diabetes, self-observation, and self-regulating activities.
PRO-DM-Thai ${ }^{\mathrm{n}}$ [47]; DQOL ${ }^{\mathrm{o}}$ (Chinese version) [48,49]; DQOL (Iranian version) [50]; DQOL (Turkish version) [51]; DQOL (Malay version) [52]; IRDQOL $^{\mathrm{p}}$ [28]; revised version of DQOL [53]; AsianDQOL ${ }^{\mathrm{q}}$ [54]; AsianDQOL (Malay version) [54]; AsianDQOL (Chinese-mandarin version) [54]; DQL-BCI $^{\mathrm{r}}$ (Polish version) [55]; ${ }^{\mathrm{s}} \mathrm{DQOL}-\mathrm{B}$ [56]; QOLID ${ }^{\mathrm{t}}$ [57]; J-DQOL ${ }^{\mathrm{u}}$ [58]; $\mathrm{QOL}^{\mathrm{v}}$ questionnaire [59]; DMQoL ${ }^{\mathrm{w}}$ (Persian version) [60]; MENQOL ${ }^{\mathrm{x}}$ [61]; Diabetes-39 (Arabic version) [62]; Diabetes-39 (Brazillian version) [63]; ADDQoL19 ${ }^{\mathrm{y}}$ [56], [64-66]; ADDQoL-19 (Chinese version) [67]; ADDQoL-19 (Malay version) [64]; CN-ADDQoL ${ }^{\mathrm{z}}$ [68]; ADDQoL (Spanish version) [69]; ADDQoL (Turkish version) [70]; Malay ADDQoL [71]; Elasy et al [72]; DHP-1 ${ }^{\text {aa }}$ [73]; DHP-3D ${ }^{\mathrm{ab}}$ [74]; DHP-5D ${ }^{\mathrm{ac}}$ [74]; DCP ${ }^{\mathrm{ad}}$ (Chinese version) [75]; DIMS ${ }^{\text {ae }}$ (Chinese version) [76]

$\mathrm{MDQ}^{\mathrm{af}}$ [77]; MDQ (Hindi version) [78]; $\mathrm{PGWB}^{\mathrm{ag}}[33]$; $\mathrm{WBQ}^{\mathrm{ah}}[26,79]$; W-BQ28 ${ }^{\mathrm{ai}}[80]$; WHO-5 ${ }^{\text {aj }}$ [81]; WHO-5 (Polish version) [82]

CES-Depression $^{\mathrm{ak}}$ [83-86]; Depression in Diabetes Self-Rating Scale [87]; SCAD ${ }^{\text {al }}$ [84]; HADS ${ }^{\text {am }}$ [84]; DMI ${ }^{\text {an }}$ [84]; EDS $^{\text {ao }}$ [88]; DCS $^{\text {ap }}$ [89]; CUDOS-Chinese ${ }^{\text {aq }}$ [90]; PHQ-9 ${ }^{\text {ar }}$ [91], [92]; PHQ-9 (Chichewa version) [93]; PHQ-9 (Romanian version) [94]

CDDS-17 ${ }^{\text {as }}$ [95]; DDS Bahasa Indonesia ${ }^{\text {at }}$ [96]; PAID ${ }^{\text {au }}$ [97]; MY-PAID-20 $^{\text {av }}$ [98]; B-PAID ${ }^{\text {aw }}$ [99]; PAID-K ${ }^{\text {ax }}$ [100]; KPAID $^{\text {ay }}$ [101]; K-PAID-5 ${ }^{\text {az }}$ [101]; Turkish PAID [102]; PAID (Greek version) [103]; SG-PAID-C ${ }^{\text {ba }}$ [104]; PAID (Spanish version) [105]; IR-PAID-20 ${ }^{\text {bb }}$ [106]

SE-Type $2^{\text {bc }}$ [107]; DMSES ${ }^{\text {bd }}$ [109]; K-DMSES ${ }^{\text {be }}$ [110]; GRDMSES $^{\text {bf }}$ [111]; DMSES (Brazilian version) [112]; IT-DM$\mathrm{SES}^{\text {bg }}$ [113]; DSEQ ${ }^{\text {bh }}$ (Thai version) [114]; CDMSS-11 ${ }^{\text {bi }}$ [115]; DSCAS ${ }^{\text {bj }}$ [116]; DSES ${ }^{\text {bk }}$ [116]; K-DSES ${ }^{\text {bl }}$ [117]; Situational Self-Efficacy Scales (Spanish version) [31]; ESS ${ }^{\text {bm }}$ [118]; Self-Efficacy for Exercise 1 (Spanish version) [31]; Self-Efficacy for Exercise 2 (Spanish version) [31]; PTES ${ }^{\text {bn }}$ [108] 


\begin{tabular}{ll}
\hline Category & Description \\
\hline Self-management & $\begin{array}{l}\text { PROMs that assess the level of diabetes self-management } \\
\text { (ie, range of activities in which individuals must engage } \\
\text { on a regular basis to manage their diabetes [119]). } \\
\text { Examples of domains assessed include general diet, spe- } \\
\text { cific diet, exercise, medication taking, blood-glucose } \\
\text { testing, foot care, and cigarette smoking. }\end{array}$
\end{tabular}

$\mathrm{PROMs}^{\mathrm{a}}$

SDSCA $^{\text {bo }}$ [120]; SDSCA (Turkish version) [121]; SDSCA$\mathrm{G}^{\mathrm{bp}}$ [122]; SDSCA (Moroccan version) [123]; SDSCA-Ar ${ }^{\mathrm{bq}}$ [124]; SDSCA-K ${ }^{\text {br }}$ [125]; INAAP-DM2 ${ }^{\text {bs }}$ [126]; SCI-R ${ }^{\text {bt }}$ [127]; DSSCI ${ }^{\text {bu }}$ [128]; SUGAAR ${ }^{\text {bv }}$ [129]; D-SMART ${ }^{\text {bw }}$ [119]; ES-SMBPA-2D $^{\text {bx }}$ [130]; DSMS ${ }^{\text {by }}$ [116]; DSMQ ${ }^{\text {bz }}$ (Thai version) [131]; DSMQ (Urdu version) [132]; V-DSMI ${ }^{\mathrm{ca}}$ [133]; DSMI-20 $^{\text {cb }}$ [134]; DSMB-O ${ }^{\text {cc }}$ [135]; SMP-T2D ${ }^{\text {cd }}$ [136]; PAM13 $^{\text {ce }}$ [137]; Chernyak et al [138]; CIRS $^{\text {cf }}$ (Thai version) [139]

Impact of empowerment tools

Health-promoting lifestyle behaviors

Health beliefs

Knowledge/ competence

Treatment experience

Treatment compliance
- $\quad$ PROMs that assess the level of empowerment (ie, patients' natural capacity and ability to become responsible for their own lives) that is discovered and developed [140] as a result of educational interventions.

- Examples of domains assessed include managing the psychosocial aspects of diabetes, assessing dissatisfaction, and readiness to change.

- $\quad$ PROMs that assess health-promoting lifestyle behaviours of patients with diabetes.

- Examples of domains assessed include physical activity, risk reduction, stress management, health responsibility, enjoyment of life, and healthy diet.

- $\quad$ PROMs that assess diabetes-specific health beliefs of patients.

- Examples of domains assessed include perceived benefits of and barriers to treatment and perceived severity of and vulnerability to complications.

- PROMs that assess the level of diabetes knowledge, whether in general or for specific areas of knowledge such as nutrition knowledge.

- Examples of domains assessed include symptoms (eg, frequent hunger), causes and risk factors (eg, lack of physical activity), complications (eg, kidney failure), and management (eg, reduced consumption of rice).

PROMs that assess the treatment experience in general [168] or specifically the level of satisfaction with treatment [79] or treatment burden [169] or treatment with specific modalities of treatment (eg, with pharmacotherapy [169] or insulin therapy [170]).

- $\quad$ Examples of domains assessed include efficacy, treatment burden and symptoms (side effects), diabetes worries, perceptions of insulin therapy, treatment satisfaction, and inhaler performance.

- $\quad$ PROMs that measure the level of compliance to treatment/adherence to medication/patients' beliefs regarding treatment.

- Examples of domains assessed include emotional difficulties in compliance, physical difficulties in compliance, changing difficulties of habits in compliance, acceptance difficulties in compliance, awareness difficulties in compliance, diet difficulties in compliance, and denial difficulties in compliance.
IR-DES-28 ${ }^{\text {cg }}$ [140]; Hara et al [141]; DES-M ${ }^{\text {ch }}$ [142]; DES$\mathrm{SF}^{\mathrm{ci}}$ (Brazilian Portuguese version) [143]; DES-SF (Portuguese version) [144]

T2DHPS $^{\text {cj }}$ (Persian version) [145]; T2DHPS (Turkish version) [146]; DHPSC ${ }^{\mathrm{ck}}$ (Chinese version) [147]; PDQ-11 ${ }^{\mathrm{cl}}$ [148]; C-PDQ ${ }^{\mathrm{cm}}[149]$

Health Belief Measures [150]; Given Health Belief Instrument (Spanish version) [151]; Health Belief Model Scale (Turkish version) [152]; Diabetes Health Belief Measure [153]

Diabetes Questionnaire [154]; Diabetes Questionnaire (Spanish version) [154]; Diabetes Knowledge Questionnaire (Spanish version) [31]; DKQ-24 ${ }^{\mathrm{cn}}$ [153]; DMKT ${ }^{\mathrm{co}}$ [155]; PCSD-P [156]; Miller et al [157]; Miller and Edwards [158]; PDDC ${ }^{\mathrm{cq}}$ [159]; DRNK ${ }^{\mathrm{cr}}$ [160]; FCCHL ${ }^{\mathrm{cs}}$ (Norwegian version) [161]; KHLS-DM $^{\text {ct }}$ [162]; HLS-K ${ }^{\text {cu }}$ [163]; HLS/SNS ${ }^{\text {cv }}$ [164]; Ashok et al 1 [165]; Ashok et al 2 [166]; HLS-EU-Q47 ${ }^{\mathrm{cw}}$ [167]

$\operatorname{DTSQ}^{\mathrm{cx}}$ [79]; DTSQ (Greek version) [171]; DiabMedSat ${ }^{\text {cy }}$ [172]; DTBQ ${ }^{\text {cz }}$ [169]; ITEQ ${ }^{\text {da }}$ [168]; IITQ ${ }^{\text {db }}$ [170]; ITAS $^{\text {dc }}$ [173]; C-ITAS-HK ${ }^{\text {dd }}$ [174]; BITQ ${ }^{\text {de }}$ (Turkish version) [175]; Ch-ASIQ $^{\text {df }}$ [176]; MIAS ${ }^{\text {dg }}$ [177]; IMDSES ${ }^{\text {dh }}$ (Brazilian version) [178]; ITSQ ${ }^{\mathrm{di}}$ [179]; OHA-Q ${ }^{\mathrm{dj}}$ [180]; DMSRQ ${ }^{\mathrm{dk}}$ [181]

Demirtas et al [182]; MMAS ${ }^{\mathrm{dl}}$ (Thai version) [183]; modified 4-item Morisky-Green-Levine Medication Adherence Scale [184]; MMAS-8 ${ }^{\mathrm{dl}}$ (Korean version) [185]; MMAS-8 (Chinese version) [186]; MMAS-8 (French version) [187], [188]; MGLS $^{\mathrm{dm}}$ (Indonesian version) [189]; Medical Prescription Knowledge questionnaire [190]; Attitude Scale [190]; BMQ$f^{d n}$ [191]; MALMAS ${ }^{\text {do }}$ [192]; MAT OADs ${ }^{d p}$ [193]; MAT Insulin $^{\mathrm{dq}}$ [193]; ARMS-K ${ }^{\mathrm{dr}}$ [194]; Diabetes Medication System Rating Questionnaire Short-Form [195]; SR-4 ${ }^{\text {ds }}$ (French version) [187]; Zongo et al 1 [187]; Zongo et al 2 [187] 


\begin{tabular}{|c|c|}
\hline Category & Description \\
\hline & $\begin{array}{l}\text { - PROMs that assess patients' experiences/perceptions of } \\
\text { specific symptoms associated with diabetes (eg, hypo- } \\
\text { glycemia [196], fatigue [197]). } \\
\text { Examples of domains assessed include symptom concern, } \\
\text { compensatory behavior, worry, general fatigue, and } \\
\text { physical fatigue. }\end{array}$ \\
\hline $\begin{array}{l}\text { Nutrition and physical } \\
\text { activity }\end{array}$ & $\begin{array}{l}\text { PROMs that assess patients' perspectives (eg, barriers/con- } \\
\text { fidence level/knowledge) in relation to diet/nutrition and } \\
\text { exercise/physical activity. } \\
\text { Examples of domains assessed include satisfaction with } \\
\text { diet, burden of diet therapy, perceived merits of diet } \\
\text { therapy, general perception of diet, restriction of social } \\
\text { functions, vitality, and mental health. }\end{array}$ \\
\hline Sleep & $\begin{array}{l}\text { PROMs that assess patients' sleep symptoms in general } \\
\text { or specific sleep-related issues, such as obstructive sleep } \\
\text { apnea symptoms [208]. }\end{array}$ \\
\hline
\end{tabular}

Support

Attitude/coping with diabetes

Obstacles and problem-solving

Health perception
- $\quad$ PROMs that assess patients' perspectives on availability of resources/support for the management of diabetes.

- Examples of domains assessed include individualized assessment, collaborative goal setting, enhancing skills, ongoing follow-up and support, and community resources.

- $\quad$ PROMs that assess perception toward disease, such as self-stigma (patients' own negative attitude toward themselves [215]), relationship consciousness [216] or awareness of the psychological burden of disease [217].

- Examples of domains assessed include cognitive, affective, behavioral, psychological impact of diabetes, sense of self-control, and efforts for symptom management.

- $\quad$ PROMs that assess patients' perspectives on obstacles to self-management/approach to manage problems in diabetes self-management/ desire to participate in medical decision-making.

- Examples of domains assessed include desire for discussion and desire for information, medication, self-monitoring, knowledge and beliefs, diagnosis, relationships with health care professionals, lifestyle changes, coping, and advice and support.

- $\quad$ PROMs that assess patients' general perceptions on their illness/diabetes-related health satisfaction and knowledge of the disease or, specifically, the perception of fatalism (events are fixed such that humans are powerless to change them) [230].

- Examples of domains assessed include timelineacute/chronic, consequences, personal control, treatment control, illness coherence, emotional representation, and cause component.
$\mathrm{PROMs}^{\mathrm{a}}$

$\mathrm{HPQ}^{\mathrm{dt}}$ (Cyprus version) [196]; HPQ [196]; $\mathrm{CHI}^{\mathrm{du}}$ (Filipino version) [198]; FH-15 ${ }^{\mathrm{dv}}$ (Chinese version) [199]; K-DSC-R ${ }^{\mathrm{dw}}$ [200]; DSC-R ${ }^{\mathrm{dx}}$ [201]; Naegeli et al [202]; FACIT ${ }^{\mathrm{dy}}$-Fatigue Scale [197]

Barriers to Fat Reduction Scale ${ }^{\mathrm{dz}}$ (Spanish version) [31]; Barriers to Exercise Checklist (Spanish version) [31]; Food Habits Questionnaire (Spanish version) [31]; DDRQOL ${ }^{\mathrm{dz}}$ [203]; DDRQOL-R ${ }^{\text {ea }}$ [204]; Sato et al [204]; IW-SP ${ }^{\text {eb }}$ [205]; Motiva.Diaf-DM2 questionnaire [206]; HAPA-based PA inventory $^{\text {ec }}$ [207]

STOP-Bang questionnaire [208]; PROMIS ${ }^{\text {ed }}$-Sleep Disturbance instrument [209]; PROMIS-Sleep Related Impairment instrument [209]

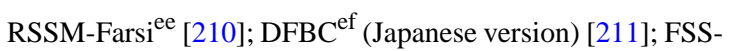
AA T2DM ${ }^{\text {eg }}$ [212]; HCCQ-P ${ }^{\text {eh }}$ [213]; The Diabetes Family Support and Conflict Scale (Turkish version) [214]

SSS-J $^{\text {ei }}$ [215]; DSAS-2 ${ }^{\text {ej }}$ [218]; Relationship Consciousness of Japanese Patients with Type 2 Diabetes Mellitus Scale [216]; ADS $^{\mathrm{ek}}$ (Japanese version) [217]; ADS (Korean version) [219]; DAAS ${ }^{\text {el }}$ [220]; IR-DAS-3 ${ }^{\text {em }}$ [221]; GCQ ${ }^{\text {en }}$ [222]; DIAB-Q $^{\text {eo }}$ [223]; S-BRCS ${ }^{\text {ep }}$ [224]

DPMD $^{\text {eq }}$ [225]; DOQ ${ }^{\text {er }}$ [226]; DOQ (Dutch version) [227]; DOQ-30 ${ }^{\text {es }}[228] ;$ DPSS $^{\text {et }}[229]$

IPQ-R $^{\text {eu }}$ [231]; CHES-Q ${ }^{\text {ev }}$ [232]; MBIPQ ${ }^{\text {ew }}$ [233]; DFS ${ }^{\text {ex }}$ [230]

\footnotetext{
apROMs: patient-reported outcome measures.

${ }^{b}$ WHOQOL-100: World Health Organization Quality of Life questionnaire.

${ }^{\mathrm{c}}$ WHOQOL-BREF: abbreviated World Health Organization Quality of Life questionnaire.

${ }^{\mathrm{d}}$ RAND-12: Veterans RAND 12-Item Health Survey.

${ }^{\mathrm{e}} \mathrm{HSQ}$ 2.0: Health Status Questionnaire 2.0.

${ }^{\mathrm{f}} \mathrm{HUI} 2$ : Health Utilities Index Mark 2.

${ }^{\mathrm{g}}$ HUI3: Health Utilities Index Mark 3.

${ }^{\mathrm{h}}$ EQ-5D: EuroQol 5-Dimension.

${ }^{\mathrm{i}}$ EQ-5D-5L: EuroQol 5-Dimension with 5-level scale.
} 
${ }^{\mathrm{j}}$ EQ-5D-3L: EuroQol 5-Dimension with 3-level scale.

kPACIC: Patient Assessment of Chronic Illness Care.

${ }^{1}$ SF-36: 36-Item Short Form Survey.

${ }_{\mathrm{m}}^{\mathrm{SF}-12 \mathrm{v} 2 \text { : Short Form-12 Health Survey version } 2 .}$

${ }^{\mathrm{n}}$ PRO-DM-Thai: instrument for patient-reported outcomes in Thai patients with type 2 diabetes mellitus.

${ }^{\circ}$ DQOL: Diabetes Quality-of-Life Measure.

PIRDQOL: Iranian Diabetes Quality of Life.

${ }^{\mathrm{q}}$ AsianDQOL: Asian Diabetes Quality of Life.

${ }^{r}$ DQL-BCI: Diabetes Quality of Life-Brief Clinical Inventory.

${ }^{\mathrm{s}}$ DQOL-B: Diabetes Quality of Life Brief Clinical Inventory.

${ }^{t}$ QOLID: Quality of Life Instrument for Indian Diabetes Patients.

uJ-DQOL: Japanese version of the Diabetes Quality-Of-Life Measure.

${ }^{\mathrm{V}} \mathrm{QOL}$ : quality of life.

${ }^{\mathrm{w}}$ DMQoL: Diabetes-Mellitus Specific Quality of Life.

${ }^{x}$ MENQOL: Menopause-specific Quality of Life.

${ }^{\mathrm{y}}$ ADDQoL-19: 19-item Audit of Diabetes-Dependent Quality of Life.

${ }^{\mathrm{z}} \mathrm{CN}$-ADDQoL: Adaptation of the ADDQoL questionnaire to people with diabetes in China

${ }^{\text {aa }}$ DHP-1: Diabetes Health Profile.

${ }^{a b}$ DHP-3D: Diabetes Health Profile-3 Dimension.

${ }^{\mathrm{ac}}$ DHP-5D: Diabetes Health Profile-5 Dimension.

${ }^{\mathrm{ad}}$ DCP: Diabetes Care Profile.

${ }^{\text {ae }}$ DIMS: diabetes impact measurement scales.

${ }^{a f}$ MDQ: Multidimensional Diabetes Questionnaire.

${ }^{\mathrm{ag}}$ PGWB: Psychological General Well-Being Questionnaire.

${ }^{\mathrm{ah}}$ WBQ: Well-being Questionnaire.

${ }^{\text {ai } W-B Q 28: ~ 28-i t e m ~ W e l l-B e i n g ~ Q u e s t i o n n a i r e . ~}$

${ }^{\text {aj }}$ WHO-5: 5-item World Health Organization well-being index.

${ }^{\mathrm{ak}}$ CES-Depression: Center for Epidemiological Studies Depression scale.

${ }^{\text {al }}$ SCAD: Silverstone Concise Assessment for Depression.

${ }^{a m}$ HADS: Hospital Anxiety and Depression Scale.

${ }^{a n}$ DMI: Depression in the Medically Ill Questionnaire.

${ }^{\mathrm{ao}}$ EDS: Edinburgh Depression Scale.

${ }^{\mathrm{ap}}$ DCS: Depressive Cognition Scale.

${ }^{a q}$ CUDOS-Chinese: Mandarin Chinese Version of the Clinically Useful Depression Outcome Scale.

${ }^{\mathrm{ar}}$ PHQ-9: Patient Health Questionnaire-9.

${ }^{\text {as }}$ CDDS-17: Chinese version of the Diabetes Distress Scale.

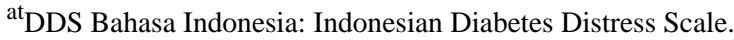

${ }^{\mathrm{au}}$ PAID: Problem Areas in Diabetes scale.

${ }^{\text {av }}$ MY-PAID-20: Malaysian version of the Problem Areas in Diabetes scale.

${ }^{a w}$ B-PAID: Brazilian version of the Problem Areas in Diabetes scale.

${ }^{a x}$ PAID-K: Korean version of the Problem Areas in Diabetes scale.

${ }^{a y}$ K-PAID: Korean translation of the Problem Areas in Diabetes scale.

${ }^{\mathrm{az}}$ K-PAID-5: Korean translation of the short form Problem Areas in Diabetes scale.

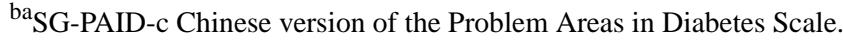

${ }^{b b}$ IR-PAID-20: Iranian version of the Problem Areas in Diabetes Scale.

${ }^{\mathrm{bc}}$ SE-Type 2: self-efficacy scale for patients with type 2 diabetes mellitus.

${ }^{b d}$ DMSES: diabetes management self-efficacy scale.

${ }^{b e}$ K-DMSES: Korean version of the diabetes management self-efficacy scale.

${ }^{\mathrm{bf}}$ GR-DMSES: Greek version of the diabetes management self-efficacy scale.

${ }^{b g}$ IT-DMSES: Italian version of the diabetes management self-efficacy scale.

${ }^{b h}$ DSEQ: Self-Efficacy for Diabetes Scale.

${ }^{\text {bi }}$ CDMSS-11: Chinese version of the Diabetes Medication Self-efficacy Scale.

${ }^{b j}$ DSCAS: Diabetes Self-Care Agency Scale.

${ }^{b k}$ DSES: Diabetes Self-efficacy Scale. 
${ }^{\mathrm{bl}} \mathrm{K}$-DSES: Korean version of the Diabetes Self-efficacy Scale.

${ }^{b m}$ ESS: Exercise Self-efficacy Scale.

${ }^{b n}$ PTES: Perceived Therapeutic Efficacy Scale.

${ }^{\text {bo }}$ SDSCA: Summary of diabetes self-care activities measure.

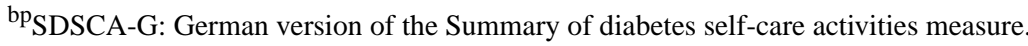

${ }^{\mathrm{bq}}$ SDSCA-Ar: Arabic version of the Summary of diabetes self-care activities measure.

${ }^{\mathrm{br}}$ SDSCA-K: Korean version of the Summary of diabetes self-care activities measure.

${ }^{\mathrm{bs}}$ INAAP-DM2: Self-care Assessment Instrument for patients with type 2 diabetes mellitus.

${ }^{\mathrm{bt}} \mathrm{SCI}-\mathrm{R}$ : Self-Care Inventory-Revised.

${ }^{\mathrm{bu}}$ DSSCI: Diabetes Symptom Self-Care Inventory.

${ }^{\text {bv }}$ SUGAAR: Self-Care Utility Geriatric African-American Rating.

${ }^{b w}$ D-SMART: Diabetes Self-management Assessment Report Tool.

${ }^{b x}$ ES-SMBPA-2D: evaluation scale for self-management behavior related to physical activity of type 2 diabetic patients.

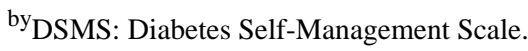

${ }^{\mathrm{bz}}$ DSMQ: Diabetes Self-management Questionnaire.

${ }^{\mathrm{ca}}$ V-DSMI: Vietnamese version of the Diabetes Self-Management Instrument.

${ }^{\mathrm{cb}}$ DSMI-20: Diabetes Self-Management Instrument Short Form.

${ }^{\mathrm{cc}}$ DSMB-O: Diabetes Self-Management Behavior for Older Koreans.

${ }^{\mathrm{cd}}$ SMP-T2D: self-management profile for type 2 diabetes.

${ }^{\text {ce }}$ PAM13: Patient Activation Measure 13.

${ }^{\mathrm{cf}}$ CIRS: Chronic Illness Resources Survey.

${ }^{\mathrm{cg}}$ IR-DES-28: Iranian version of the Diabetes Empowerment Scale.

${ }^{\mathrm{ch}}$ DES-M: diabetes empowerment scale.

${ }^{c i}$ DES-SF: Diabetes Empowerment Scale-Short Form.

${ }^{c j}$ T2DHPS: Type 2 Diabetes and Health Promotion Scale.

${ }^{\mathrm{ck}}$ DHPSC: diabetes health promotion self-care scale.

${ }^{\mathrm{cl}}$ PDQ-11: Personal Diabetes Questionnaire.

${ }^{\mathrm{cm}} \mathrm{C}-\mathrm{PDQ}$ : Chinese version of the Personal Diabetes Questionnaire.

${ }^{\mathrm{cn}}$ DKQ-24: Diabetes Knowledge Questionnaire-24.

${ }^{\mathrm{co} D M K T: ~ D i a b e t e s ~ M e l l i t u s ~ K n o w l e d g e ~ T e s t . ~}$

${ }^{\mathrm{cp}}$ PCSD-P: Persian Version of the Perceived Competence Scale for Diabetes.

${ }^{\mathrm{cq}}$ PDDC: measure of perceived diabetes and dietary competence.

${ }^{\mathrm{cr}}$ DRNK: diabetes-related nutrition knowledge questionnaire.

${ }^{c s}$ FCCHL: Functional, Communicative, and Critical Health Literacy Scale.

${ }^{c t}$ KHLS-DM: Korean Health Literacy Scale for Diabetes Mellitus.

${ }^{\mathrm{cu}}$ HLS-K: Health Literacy Scale.

${ }^{\mathrm{cv}}$ HLS/SNS: Health Literacy Scale/Subjective Numeracy Scale.

${ }^{\mathrm{cw}}$ HLS-EU-Q47: European Health Literacy Survey Questionnaire.

${ }^{\mathrm{cx}}$ DTSQ: Diabetes Treatment Satisfaction Questionnaire.

${ }^{\mathrm{cy}}$ DiabMedSat: Diabetes Medication Satisfaction measure.

${ }^{\mathrm{cz} D T B Q: ~ D i a b e t i c ~ T r e a t m e n t ~ B u r d e n ~ Q u e s t i o n n a i r e . ~}$

${ }^{\mathrm{da}}$ ITEQ: insulin treatment experience questionnaire.

${ }^{\mathrm{db}}$ IITQ: inhaled insulin treatment questionnaire.

${ }^{\mathrm{dc}}$ ITAS: Insulin Treatment Appraisal Scale.

${ }^{\mathrm{dd}}$ C-ITAS-HK: Hong Kong version of the Chinese Insulin Treatment Appraisal Scale.

${ }^{\mathrm{de}}$ BITQ: Barriers to Insulin Treatment Questionnaire.

${ }^{\mathrm{df}}$ Ch-ASIQ: Chinese Attitudes to Starting Insulin Questionnaire.

${ }^{\mathrm{dg}}$ MIAS: Morisky Medication Adherence Scale adapted to specify insulin adherence.

${ }^{\mathrm{dh}}$ IMDSES: Insulin Management Diabetes Self-Efficacy Scale.

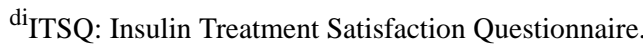

${ }^{d j}$ OHA-Q: Oral Hypoglycemic Agent Questionnaire.

${ }^{\mathrm{dk}}$ DMSRQ: Diabetes Medication System Rating Questionnaire.

${ }^{\mathrm{dl}}$ MMAS-8: 8-item Morisky Medication Adherence Scale.

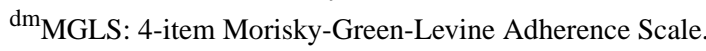


${ }^{d n}$ BMQ-f: French version of the Beliefs about Medicines Questionnaire.

${ }^{\text {do }}$ MALMAS: Malaysian Medication Adherence Scale.

${ }^{\mathrm{dp}}$ MAT OADs: Measurement of Adherence to Drug Therapy in Diabetes Mellitus-Oral Antidiabetics.

${ }^{\mathrm{dq}}$ MAT Insulin: Measurement of Adherence to Drug Therapy in Diabetes Mellitus-Insulin Therapy.

${ }^{\mathrm{dr}}$ ARMS-K: Korean version of the Adherence to Refills and Medications Scale.

${ }^{\mathrm{ds}} \mathrm{SR}-4$ : self-report with 4 items.

${ }^{\mathrm{dt}} \mathrm{HPQ}$ : Hypoglycemia Perspectives Questionnaire.

${ }^{\mathrm{du}} \mathrm{CHI}$ : Clarke Hypoglycemia Index.

${ }^{d v}$ FH-15: Chinese version of the new Fear of Hypoglycemia scale.

${ }^{\mathrm{dw}} \mathrm{K}-\mathrm{DSC}-\mathrm{R}$ : Korean version of the Diabetes Symptom Checklist-Revised.

${ }^{\mathrm{dx}}$ DSC-R: Diabetes Symptom Checklist-Revised.

${ }^{d y}$ FACIT: Functional Assessment of Chronic Illness Therapy.

${ }^{\mathrm{dz}}$ DDRQOL: Diabetes Diet-Related Quality-of-Life scale.

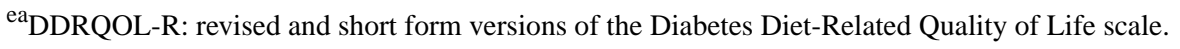

${ }^{\mathrm{eb}}$ IW-SP: Impact of Weight on Self-Perceptions Questionnaire.

${ }^{\mathrm{ec}}$ HAPA-based PA inventory: health action process approach (HAPA)-based physical activity inventory.

${ }^{\text {ed }}$ PROMIS: Patient-Reported Outcomes Measurement Information System.

${ }^{e e}$ RSSM-Farsi: Iranian version of Resources and Support for Chronic Illness Self-management scale.

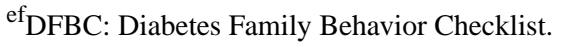

${ }^{\text {eg }}$ FSS-AA T2DM: Family Support Scale Adapted for African American Women with Type 2 Diabetes Mellitus.

${ }^{\text {eh }}$ HCCQ-P: Persian Health Care Climate Questionnaire.

${ }^{\text {ei }}$ SSS-J: Japanese version of the Self-Stigma Scale.

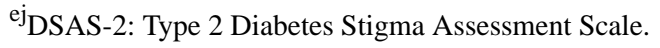

${ }^{e k}$ ADS: Appraisal of Diabetes Scale.

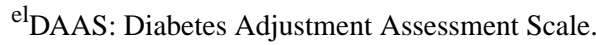

em IR-DAS-3: Iranian Diabetes Attitude Scale.

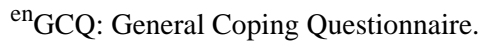

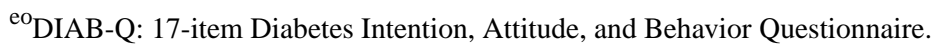

${ }^{\mathrm{ep}}$ S-BRCS: Spanish Brief Religious Coping Scale.

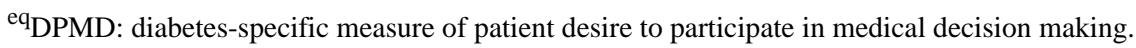

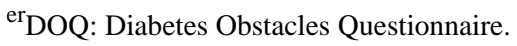

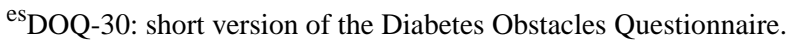

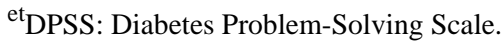

${ }^{\mathrm{eu}} \mathrm{IPQ}$-R: Revised Illness Perception Questionnaire.

${ }^{\mathrm{ev}}$ CHES-Q: 14-item Current Health Satisfaction Questionnaire.

${ }^{\text {ew }}$ MBIPQ: Malay version of the Brief Illness Perception Questionnaire.

${ }^{e x}$ DFS: 12-item Diabetes Fatalism Scale.

\section{Assessment of Methodological Quality and Quality of Measurement Properties}

The results from the assessment of methodological quality and quality of measurement properties of the PROMs are presented in Table S5 of Multimedia Appendix 1. In terms of validity, hypothesis testing for construct validity, structural validity, and content validity were measured for $46.8 \%$ (116/248), $49.2 \%$ (122/248), and $29.0 \%$ (72/248) of the studies, respectively. In terms of reliability, internal consistency and reliability were assessed in 79.0\% (196/248) and 41.9\% (104/248) of the studies, respectively.

\section{Evidence Synthesis}

The results from the evidence synthesis of the PROMs are summarized in Table S6 in Multimedia Appendix 1. PROMs with at least a moderate level of evidence for $\geq 5$ measurement properties include the Chinese version of the Personal Diabetes Questionnaire (C-PDQ) and the Insulin Treatment Appraisal
Scale in Hong Kong primary care patients (C-ITAS-HK), of which the C-PDQ has a sufficient (+) rating for at least 4 measurement properties.

\section{Recommendations}

According to the COSMIN guidelines [15], PROMs that have evidence for sufficient content validity and at least low-quality evidence for sufficient internal consistency can be recommended for use, and the results obtained with these PROMs can be trusted. The 43 PROMs that meet these criteria are shaded in Table S6 in grey and presented in Table S7 (Multimedia Appendix 1). They are listed below according to the categorization we have proposed in Table 3:

1. General impact on quality of life: Health Status Questionnaire 2.0 (HSQ 2.0) (Spanish version), Patient Assessment of Chronic Illness Care (PACIC)

2. Diabetes-specific impact on quality of life: instrument for patient-reported outcomes in Thai patients with type 2 
diabetes mellitus (PRO-DM-Thai), Diabetes Quality-of-Life Measure (DQOL), Asian DQOL

3. Diabetes-related depression: Mandarin Chinese Version of the Clinically Useful Depression Outcome Scale (CUDOS-Chinese), Patient Health Questionnaire-9 (PHQ-9).

4. Self-efficacy: diabetes management self-efficacy scale (DMSES), Situational Self-Efficacy Scales (Spanish version), Self-Efficacy for Exercise 1 (Spanish version), Self-Efficacy for Exercise 2 (Spanish version)

5. Self-management: Diabetes Self-management Questionnaire (DSMQ), Diabetes Self-Management Instrument Short Form (DSMI-20), Chronic Illness Resources Survey (CIRS) (Thai version)

6. Impact of empowerment tools: Diabetes Empowerment Scale-Short Form (DES-SF)

7. Lifestyle behaviors: Type 2 Diabetes and Health Promotion Scale (T2DHPS), diabetes health promotion self-care scale (DHPSC) (Chinese version), C-PDQ

8. Health beliefs: Health belief model (Turkish version)

9. Knowledge/competence: Diabetes Knowledge Questionnaire (Spanish version), Diabetes Mellitus Knowledge Test (DMKT), Persian Version of Perceived Competence Scale for Diabetes (PCSD-P), Miller et al [157], the diabetes-related nutrition knowledge questionnaire (DRNK), Korean Health Literacy Scale for Diabetes Mellitus (KHLS-DM).

10. Treatment experience: C-ITAS-HK, Chinese Attitudes to Starting Insulin Questionnaire (CH-ASIQ).

11. Treatment compliance: Medical Prescription Knowledge questionnaire, Attitude Scale, Measurement of Adherence to Drug Therapy in Diabetes Mellitus-Oral Antidiabetics (MAT OADS), Measurement of Adherence to Drug Therapy in Diabetes Mellitus-Insulin Therapy (MAT insulin).

12. Symptoms: new fear of hypoglycemia scale (FH-15) (Chinese version), Functional Assessment of Chronic Illness Therapy (FACIT)-Fatigue Scale.

13. Nutrition and physical activity: Barriers to Fat Reduction Scale (Spanish version), Barriers to Exercise Checklist (Spanish version), Food Habits Questionnaire (Spanish version), health action process approach (HAPA)-based PA inventory

14. Support: Persian Health Care Climate Questionnaire (HCCQ-P), the Diabetes Family Support and Conflict Scale (Turkish version)

15. Attitude/coping with diabetes: Relationship Consciousness of Japanese Patients with Type 2 Diabetes, Diabetes Adjustment Assessment Scale (DAAS)

16. Obstacles and problem-solving: diabetes-specific measure of patient desire to participate in medical decision making (DPMD), Diabetes Obstacles Questionnaire (DOQ)

\section{Discussion}

\section{Principal Findings}

To the best of our knowledge, this is the first systematic review to attempt to comprehensively summarize and categorize the PROMs for type 2 diabetes and to assess their overall level of evidence based on the COSMIN guidelines. Among the 248 included studies, we identified 238 unique PROMs for patients with type 2 diabetes, with 43 unique PROMs meeting the COSMIN guidelines for recommendation for use. While our study identified a wide range of unique PROMs, based on the number of studies for each PROM (in Table S6, Multimedia Appendix 1), most of the PROMs have been validated by very few studies that evaluated them in the Type 2 diabetes population, which may bias the assessment of methodological quality and quality of measurement properties.

Nevertheless, according to the COSMIN guidelines [15], PROMs that have been validated by at least one study showing sufficient content validity and at least low quality evidence for sufficient internal consistency can be recommended for use. Our review has included recommendations for various PROM categories that should be helpful for clinicians and academics.

As illustrated in Table 3, the 43 unique PROMs identified and recommended for use measure a wide range of clinically relevant domains, ranging from impact on quality of life to specific issues such as treatment experience/treatment compliance for clinicians and researchers to apply in clinical practice. Further validation studies can also be conducted on the remaining 189 PROMs that do not meet the COSMIN guidelines for recommendation.

Measurement error was assessed in only one study, as the other studies did not report standard error of measurement, smallest detectable change, or limits of agreement as required by the COSMIN. This may be addressed in future research. In addition, although PROM translations were performed for 122 out of the 248 studies (49.2\%), none of these studies assessed measurement invariance or differential item functioning; therefore, cross-cultural validity was not evaluated for any of the PROMs in this study. Further studies on measurement error and cross-cultural validity of medication adherence PROM are warranted for these studies.

\section{Strengths and Limitations}

Our study has several strengths. We used three databases and sensitive search filters to capture as many potentially relevant articles as possible. The rigor of the study was established using the PRISMA statement and the COSMIN guidelines, which are well regarded as a consensus-based standard for evaluating the measurement properties of PROMs. The COSMIN Risk of Bias checklist employed in this study is an improvement from the original COSMIN checklist, with several improvements in the standards for evaluation [14,15]. As far as possible, we have also aimed to adopt the COSMIN guidelines for reporting the results of our evaluation. The PRISMA statement was used because it improves the transparency and clarity of the systematic review [234]. Moreover, in Table 3, we categorized all the PROMs based on their types of outcome measures. In addition to having highlighted 43 unique PROMs that are recommended for use under the COSMIN guidelines, the categorization we have proposed will provide readers with a range of options for selecting the most appropriate or robust PROM according to their required domain of assessment.

Our study has some limitations. One limitation related to this study is that the selection and evaluation of articles were 
subjective in nature and may have been prone to judgment bias. Further, given the scope of our study, there is inevitable potential for remaining inaccuracies in the data review/extraction process. Nevertheless, the requirement by COSMIN to have two independent reviewers and the need for a third reviewer to reach a consensus in the case of any discrepancy helps reduce the risk of judgement bias [15] and reduces the likelihood of any inaccuracies. Further, this study included only English full-text articles. Full-text articles were necessary, as they are peer-reviewed and recommended for inclusion by Terwee et al [235].

Further, in terms of the scope of our literature review, the PROMs identified may have been validated in other disease populations, or versions of the same PROMs may have been translated into other languages or culturally adapted to other populations; thus, they may have been validated in separate studies not captured by our literature review. For the validation studies of the PROMs that were identified, given the high number of studies retrieved, we were unable to hand-search all the references of the studies retrieved, and there may be additional relevant studies that were not included. Thus, such studies would be outside the scope of this review.
Finally, in comparison with previous systematic reviews on diabetes PROMs (ie, PROMs evaluating only health-related quality of life measures [8], PROMs for diabetes self-care [9], PROMs in patients with diabetes associated with foot and ankle pathologies [10], or the use of PROMs/association of PROMs with diabetes and its complications [11]), a direct comparison to the PROMs reviewed by these prior studies, which focused on diabetes complications, could not be made in this review, which focuses on reporting the results of the PROMs on type 2 diabetes (and not including complications of diabetes) identified from our review. The results of our systematic review for PROMs on the complications of diabetes will be reported separately.

\section{Conclusion}

This review has identified 238 unique PROMs for type 2 diabetes through a systematic review and evaluated their level of evidence, adjusted using results from an assessment of methodological quality. Based on the COSMIN guidelines for evidence synthesis, PROMs with at least a moderate level of evidence for $\geq 5$ measurement properties include the C-PDQ, DSMI-20, and the C-ITAS-HK, of which the C-PDQ has sufficient $(+)$ ratings for at least 4 measurement properties, and based on the COSMIN guidelines, 43 unique PROMs can be recommended for use.

\section{Acknowledgments}

We would like to thank Librarian Ms Wong Suei Nee at the National University of Singapore Medical Library for her advice on search strategies. This research is supported by the AM-ETHOS Duke-NUS Medical Student Fellowship Award and the Ministry of Health Singapore National Innovation Challenge Grant on Chronic Diseases Management (MOH/NIC/CDM1/2018).

\section{Conflicts of Interest}

None declared.

\section{Multimedia Appendix 1}

Supplementary material. [DOCX File, $291 \mathrm{~KB}-$ Multimedia Appendix 1]

\section{References}

1. IDF Diabetes Atlas, 9th edition. International Diabetes Federation. 2019. URL: https://www.diabetesatlas.org [accessed 2020-08-01]

2. American Diabetes Association. 1. Promoting health and reducing disparities in populations. Diabetes Care 2016 Dec 15;40(Supplement 1):S6-S10 [FREE Full text] [doi: 10.2337/dc17-s004]

3. Skovlund SE, Lichtenberg T, Hessler D, Ejskjaer N. Can the routine use of patient-reported outcome measures improve the delivery of person-centered diabetes care? A review of recent developments and a case study. Curr Diab Rep 2019 Aug 16;19(9):1-18 [FREE Full text] [doi: 10.1007/s11892-019-1190-x]

4. Weldring T, Smith SM. Article Commentary: Patient-Reported Outcomes (PROs) and Patient-Reported Outcome Measures (PROMs). Health Serv Ins 2013 Aug 04;6:HSI.S11093-HSI.S11068 [FREE Full text] [doi: 10.4137/hsi.s11093]

5. Boyer JG, Earp JAL. The development of an instrument for assessing the quality of life of people with diabetes. Med Care 1997 May;35(5):440-453 [FREE Full text] [doi: 10.1097/00005650-199705000-00003]

6. Welch GW, Jacobson AM, Polonsky WH. The Problem Areas in Diabetes Scale. An evaluation of its clinical utility. Diabetes Care 1997 May 01;20(5):760-766 [FREE Full text] [doi: 10.2337/diacare.20.5.760] [Medline: 9135939]

7. Lee E, Lee YW, Lee K, Kim YS, Nam M. Measurement of diabetes-related emotional distress using the Problem Areas in Diabetes scale: psychometric evaluations show that the short form is better than the full form. Health Qual Life Outcomes 2014 Oct 29;12(1):142 [FREE Full text] [doi: 10.1186/s12955-014-0142-z] [Medline: 25358396] 
8. El Achhab Y, Nejjari C, Chikri M, Lyoussi B. Disease-specific health-related quality of life instruments among adults diabetic: A systematic review. Diabetes Res Clin Pract 2008 May;80(2):171-184. [doi: 10.1016/j.diabres.2007.12.020] [Medline: $\underline{18279993}$ ]

9. Lee J, Lee E, Chae D, Kim C. Patient-reported outcome measures for diabetes self-care: a systematic review of measurement properties. Int J Nurs Stud 2020 May;105:103498 [FREE Full text] [doi: 10.1016/j.ijnurstu.2019.103498] [Medline: 32203756]

10. Ortega-Avila A, Cervera-Garvi P, Ramos-Petersen L, Chicharro-Luna E, Gijon-Nogueron G. Patient-reported outcome measures for patients with diabetes mellitus associated with foot and ankle pathologies: a systematic review. J Clin Med 2019 Jan 27;8(2):146 [FREE Full text] [doi: 10.3390/jcm8020146] [Medline: 30691204]

11. Chen YT, Tan YZ, Cheen M, Wee H. Patient-reported outcome measures in registry-based studies of type 2 diabetes mellitus: a systematic review. Curr Diab Rep 2019 Nov 20;19(11):135 [FREE Full text] [doi: 10.1007/s11892-019-1265-8] [Medline: $\underline{31748944]}$

12. García-Inzunza JA, Valles-Medina AM, Muñoz FA, Delgadillo-Ramos G, Compean-Ortiz LG. Validity of the Mexican version of the combined Foot Care Confidence / Foot-Care Behavior scale for diabetes. Rev Panam Salud Publica 2015 Jul;38(1):35-41. [Medline: 26506319]

13. Moher D, Liberati A, Tetzlaff J, Altman DG, PRISMA Group. Preferred reporting items for systematic reviews and meta-analyses: the PRISMA statement. PLoS Med 2009 Jul 21;6(7):e1000097 [FREE Full text] [doi:

10.1371/journal.pmed.1000097] [Medline: 19621072]

14. Mokkink LB, de Vet HCW, Prinsen CAC, Patrick DL, Alonso J, Bouter LM, et al. COSMIN Risk of Bias checklist for systematic reviews of patient-reported outcome measures. Qual Life Res 2018 May 19;27(5):1171-1179 [FREE Full text] [doi: 10.1007/s11136-017-1765-4] [Medline: 29260445]

15. Prinsen CAC, Mokkink LB, Bouter LM, Alonso J, Patrick DL, de Vet HCW, et al. COSMIN guideline for systematic reviews of patient-reported outcome measures. Qual Life Res 2018 May 12;27(5):1147-1157 [FREE Full text] [doi: 10.1007/s11136-018-1798-3] [Medline: 29435801]

16. Terwee CB, Bot SD, de Boer MR, van der Windt DA, Knol DL, Dekker J, et al. Quality criteria were proposed for measurement properties of health status questionnaires. J Clin Epidemiol 2007 Jan;60(1):34-42 [FREE Full text] [doi: 10.1016/j.jclinepi.2006.03.012] [Medline: 17161752]

17. Measurement properties of patient reported outcome measures for Diabetes Mellitus: a systematic review. Open Science Framework. URL: https://osf.io/v2nwu [accessed 2021-07-12]

18. Prinsen CAC, Mokkink LB, Bouter LM, Alonso J, Patrick DL, de Vet HCW, et al. COSMIN guideline for systematic reviews of patient-reported outcome measures. Qual Life Res 2018 May;27(5):1147-1157 [FREE Full text] [doi: 10.1007/s11136-018-1798-3] [Medline: 29435801]

19. Terwee CB, Jansma EP, Riphagen II, de Vet HCW. Development of a methodological PubMed search filter for finding studies on measurement properties of measurement instruments. Qual Life Res 2009 Oct 27;18(8):1115-1123 [FREE Full text] [doi: 10.1007/s11136-009-9528-5] [Medline: 19711195]

20. COnsensus-based Standards for the selection of health Measurement INstruments (COSMIN). 2010. URL: http://www. cosmin.nl [accessed 2020-04-04]

21. Terwee CB, Prinsen CAC, Chiarotto A, Westerman MJ, Patrick DL, Alonso J, et al. COSMIN methodology for evaluating the content validity of patient-reported outcome measures: a Delphi study. Qual Life Res 2018 May 17;27(5):1159-1170 [FREE Full text] [doi: 10.1007/s11136-018-1829-0] [Medline: 29550964]

22. Mokkink LB, Terwee CB, Patrick DL, Alonso J, Stratford PW, Knol DL, et al. The COSMIN study reached international consensus on taxonomy, terminology, and definitions of measurement properties for health-related patient-reported outcomes. J Clin Epidemiol 2010 Jul;63(7):737-745 [FREE Full text] [doi: 10.1016/j.jclinepi.2010.02.006] [Medline: 20494804]

23. Terwee CB, Mokkink LB, Knol DL, Ostelo RWJG, Bouter LM, de Vet HCW. Rating the methodological quality in systematic reviews of studies on measurement properties: a scoring system for the COSMIN checklist. Qual Life Res 2012 May 6;21(4):651-657 [FREE Full text] [doi: 10.1007/s11136-011-9960-1] [Medline: 21732199]

24. Marcel Dijkers. Introducing GRADE: a systematic approach to rating evidence in systematic reviews and to guideline development. KT Update. 2013. URL: https://ktdrr.org/products/update/v1n5/dijkers grade ktupdatev1n5.pdf [accessed 2021-07-19]

25. Pibernik-Okanović M. Psychometric properties of the World Health Organisation quality of life questionnaire (WHOQOL-100) in diabetic patients in Croatia. Diabetes Res Clin Pract 2001 Feb;51(2):133-143. [doi: 10.1016/s0168-8227(00)00230-8]

26. Kolawole BA, Mosaku SK, Ikem RT. A comparison of two measures of quality of life of Nigerian clinic patients with type 2 diabetes mellitus. Afr Health Sci 2009 Sep;9(3):161-166 [FREE Full text] [Medline: 20589144]

27. Sreedevi A, Cherkil S, Kuttikattu DS, Kamalamma L, Oldenburg B. Validation of WHOQOL-BREF in Malayalam and determinants of quality of life among people with type 2 diabetes in Kerala, India. Asia Pac J Public Health 2016 Jan;28(1 Suppl):62S-69S [FREE Full text] [doi: 10.1177/1010539515605888] [Medline: 26419636] 
28. Jahanlou AS, Karami NA. WHO quality of life-BREF 26 questionnaire: reliability and validity of the Persian version and compare it with Iranian diabetics quality of life questionnaire in diabetic patients. Prim Care Diabetes 2011 Jul;5(2):103-107. [doi: 10.1016/j.pcd.2011.02.001] [Medline: 21481660]

29. Reba K, Birhane BW, Gutema H. Validity and reliability of the Amharic version of the World Health Organization's Quality of Life Questionnaire (WHOQOL-BREF) in patients with diagnosed Type 2 diabetes in Felege Hiwot Referral Hospital, Ethiopia. J Diabetes Res 2019 May 06;2019:3513159-3513156 [FREE Full text] [doi: 10.1155/2019/3513159] [Medline: 31198788]

30. Maddigan SL, Feeny DH, Johnson JA. Construct validity of the RAND-12 and Health Utilities Index Mark 2 and 3 in type 2 diabetes. Qual Life Res 2004 Mar;13(2):435-448. [doi: 10.1023/b:qure.0000018497.06539.8f]

31. Morgan BS, Buscemi CP, Fajardo VP. Assessing instruments in a Cuban American population with type 2 diabetes mellitus. J Transcult Nurs 2004 Apr 29;15(2):139-146. [doi: 10.1177/1043659603262487] [Medline: 15070496]

32. Maddigan SL, Feeny DH, Majumdar SR, Farris KB, Johnson JA. Health Utilities Index mark 3 demonstrated construct validity in a population-based sample with type 2 diabetes. J Clin Epidemiol 2006 May;59(5):472-477. [doi: 10.1016/j.jclinepi.2005.09.010] [Medline: 16632135]

33. Matza LS, Boye KS, Yurgin N. Validation of two generic patient-reported outcome measures in patients with type 2 diabetes. Health Qual Life Outcomes 2007 Jul 31;5(1):47 [FREE Full text] [doi: 10.1186/1477-7525-5-47] [Medline: 17672906]

34. Lee WJ, Song K, Noh JH, Choi YJ, Jo M. Health-related quality of life using the EuroQol 5D questionnaire in Korean patients with type 2 diabetes. J Korean Med Sci 2012 Mar;27(3):255-260 [FREE Full text] [doi: 10.3346/jkms.2012.27.3.255] [Medline: 22379335]

35. Sayah FA, Qiu W, Xie F, Johnson JA. Comparative performance of the EQ-5D-5L and SF-6D index scores in adults with type 2 diabetes. Qual Life Res 2017 Aug 31;26(8):2057-2066. [doi: 10.1007/s11136-017-1559-8] [Medline: 28364183]

36. McClure NS, Sayah FA, Ohinmaa A, Johnson JA. Minimally important difference of the EQ-5D-5L Index Score in adults with type 2 diabetes. Value Health 2018 Sep;21(9):1090-1097 [FREE Full text] [doi: 10.1016/j.jval.2018.02.007] [Medline: $\underline{30224114]}$

37. Wang P, Luo N, Tai E, Thumboo J. The EQ-5D-5L is more discriminative than the EQ-5D-3L in patients with diabetes in Singapore. Value Health Reg Issues 2016 May;9:57-62. [doi: 10.1016/j.vhri.2015.11.003] [Medline: 27881260]

38. Konerding U, Elkhuizen SG, Faubel R, Forte P, Malmström T, Pavi E, et al. The validity of the EQ-5D-3L items: an investigation with type 2 diabetes patients from six European countries. Health Qual Life Outcomes 2014 Dec 05;12(1):181 [FREE Full text] [doi: 10.1186/s12955-014-0181-5] [Medline: 25479769]

39. Koh D, Abdullah AMKB, Wang P, Lin N, Luo N. Validation of Brunei's Malay EQ-5D Questionnaire in patients with type 2 diabetes. PLoS One 2016;11(11):e0165555 [FREE Full text] [doi: 10.1371/journal.pone.0165555] [Medline: 27835652]

40. Fan J, McCoy RG, Ziegenfuss JY, Smith SA, Borah BJ, Deming JR, et al. Evaluating the structure of the Patient Assessment of Chronic Illness Care (PACIC) survey from the patient's perspective. Ann Behav Med 2015 Feb 19;49(1):104-111. [doi: 10.1007/s12160-014-9638-3] [Medline: 25236671]

41. Aung E, Donald M, Coll JR, Williams GM, Doi SAR. Association between patient activation and patient-assessed quality of care in type 2 diabetes: results of a longitudinal study. Health Expect 2016 Apr 13;19(2):356-366 [FREE Full text] [doi: 10.1111/hex.12359] [Medline: 25773785]

42. Gugiu PC, Coryn C, Clark R, Kuehn A. Development and evaluation of the short version of the Patient Assessment of Chronic Illness Care instrument. Chronic Illn 2009 Dec 19;5(4):268-276. [doi: 10.1177/1742395309348072] [Medline: 19933249]

43. Gugiu C, Coryn C, Applegate B. Structure and measurement properties of the Patient Assessment of Chronic Illness Care instrument. J Eval Clin Pract 2010 Jun;16(3):509-516. [doi: 10.1111/j.1365-2753.2009.01151.x] [Medline: 20210824]

44. Abdul-Razak S, Ramli AS, Badlishah-Sham SF, Haniff J, EMPOWER-PAR Investigators. Validity and reliability of the patient assessment on chronic illness care (PACIC) questionnaire: the Malay version. BMC Fam Pract 2018 Jul 19;19(1):119 [FREE Full text] [doi: 10.1186/s12875-018-0807-5] [Medline: $\underline{\text { 30025525] }}$

45. Hu J, Gruber KJ, Hsueh K. Psychometric properties of the Chinese version of the SF-36 in older adults with diabetes in Beijing, China. Diabetes Res Clin Pract 2010 Jun;88(3):273-281. [doi: 10.1016/j.diabres.2010.03.005] [Medline: 20392508]

46. Wan EYF, Choi EPH, Yu EYT, Chin WY, Fung CSC, Chan AKC, et al. Evaluation of the internal and external responsiveness of Short Form-12 Health Survey version 2 (SF-12v2) in patients with type 2 diabetes mellitus. Qual Life Res 2018 Sep 13;27(9):2459-2469. [doi: 10.1007/s11136-018-1908-2] [Medline: 29948606]

47. Chuayruang K, Sriratanaban J, Hiransuthikul N, Suwanwalaikorn S. Development of an instrument for patient-reported outcomes in Thai patients with type 2 diabetes mellitus (PRO-DM-Thai). Asian Biomed 2015;9:7-19. [doi: 10.5372/1905-7415.0901.363]

48. Cheng AY, Tsui EY, Hanley AJ, Zinman B. Developing a quality of life measure for Chinese patients with diabetes. Diabetes Research and Clinical Practice 1999 Dec;46(3):259-267. [doi: 10.1016/s0168-8227(99)00091-1]

49. Jin X, Liu GG, Gerstein HC, Levine MAH, Steeves K, Guan H, et al. Item reduction and validation of the Chinese version of diabetes quality-of-life measure (DQOL). Health Qual Life Outcomes 2018 Apr 27;16(1):78 [FREE Full text] [doi: 10.1186/s12955-018-0905-z] [Medline: 29703205] 
50. Pakpour A, Saffari M, Burri A. Translation and validation of an Iranian version of the Diabetes Quality of Life measure. J Diabetes Investig 2012 Oct 18;3(5):471-478 [FREE Full text] [doi: 10.1111/j.2040-1124.2012.00217.x] [Medline: 24843609]

51. Yildirim A, Akinci F, Gozu H, Sargin H, Orbay E, Sargin M. Translation, cultural adaptation, cross-validation of the Turkish diabetes quality-of-life (DQOL) measure. Qual Life Res 2007 Jun 8;16(5):873-879. [doi: 10.1007/s11136-007-9172-x] [Medline: 17286193]

52. Bujang MA, Ismail M, Hatta NKBM, Othman SH, Baharum N, Lazim SSM. Validation of the Malay version of Diabetes Quality of Life (DQOL) Questionnaire for adult population with type 2 diabetes mellitus. Malays J Med Sci 2017 Aug 18;24(4):86-96 [FREE Full text] [doi: 10.21315/mjms2017.24.4.10] [Medline: 28951693]

53. Bujang MA, Adnan TH, Mohd Hatta NKB, Ismail M, Lim CJ. A revised version of Diabetes Quality of Life Instrument maintaining domains for satisfaction, impact, and worry. J Diabetes Res 2018 Jul 22;2018:5804687-5804610 [FREE Full text] [doi: 10.1155/2018/5804687] [Medline: 30327784]

54. Goh S, Rusli B, Khalid B. Development and validation of the Asian Diabetes Quality of Life (AsianDQOL) Questionnaire. Diabetes Res Clin Pract 2015 Jun;108(3):489-498 [FREE Full text] [doi: 10.1016/j.diabres.2015.02.009] [Medline: 25790899]

55. Dudzińska M, Tarach JS, Burroughs TE, Zwolak A, Matuszek B, Smoleń A, et al. Validation of the Polish version of Diabetes Quality of Life - Brief Clinical Inventory (DQL-BCI) among patients with type 2 diabetes. Arch Med Sci 2014 Oct 27;10(5):891-898 [FREE Full text] [doi: 10.5114/aoms.2014.46210] [Medline: 25395940]

56. Magwood GS, Jenkins C, Zapka J. Validation of diabetes health-related quality-of-life instruments using cognitive interviewing with older African Americans. J Nurs Meas 2009 Dec 01;17(3):195-220 [FREE Full text] [doi: 10.1891/1061-3749.17.3.195] [Medline: 20069949]

57. Nagpal J, Kumar A, Kakar S, Bhartia A. The development of 'Quality of Life Instrument for Indian Diabetes patients (QOLID): a validation and reliability study in middle and higher income groups. J Assoc Physicians India 2010 May;58:295-304. [Medline: 21117348]

58. Sato F, Mita T, Yamamoto R, Hirose T, Ito C, Tamura Y, et al. Reliability and validity of the Japanese version of the Diabetes Quality-Of-Life questionnaire for Japanese patients with type 2 diabetes mellitus. Diabetol Int 2013 Jul 2;5(1):21-29. [doi: $10.1007 / \mathrm{s} 13340-013-0125-\mathrm{z}$ ]

59. Oobe M, Tanaka M, Fuchigami M, Sakata T. Preparation of a quality of life (QOL) questionnaire for patients with type II diabetes and prospects for its clinical application. Fukuoka Igaku Zasshi 2007 Oct;98(10):379-387. [Medline: 18046991]

60. Saffari M, Lin C, O’ Garo K, Koenig HG, Sanaeinasab H, Pakpour AH. Psychometric properties of Persian Diabetes-Mellitus Specific Quality of Life (DMQoL) questionnaire in a population-based sample of Iranians. Int J Diabetes Dev Ctries 2018 Jun 4;39(1):218-227. [doi: 10.1007/s13410-018-0648-8]

61. Hasan SS, Ahmadi K, Santigo R, Ahmed SI. The validity of the Menopause-specific Quality of Life questionnaire in women with type 2 diabetes. Climacteric 2014 Aug 30;17(4):456-464. [doi: 10.3109/13697137.2013.864269] [Medline: 24228772]

62. Khader YS, Bataineh S, Batayha W. The Arabic version of Diabetes-39: psychometric properties and validation. Chronic Illn 2008 Dec 01;4(4):257-263. [doi: 10.1177/1742395308100647] [Medline: 19091934]

63. Queiroz FAD, Pace AE, Santos CBD. Cross-cultural adaptation and validation of the instrument Diabetes - 39 (D-39): brazilian version for type 2 diabetes mellitus patients - stage 1. Rev Lat Am Enfermagem 2009;17(5):708-715 [FREE Full text] [doi: 10.1590/s0104-11692009000500018] [Medline: 19967222]

64. Jannoo Z, Yap BW, Musa KI, Lazim MA, Hassali MA. An audit of diabetes-dependent quality of life in patients with type 2 diabetes mellitus in Malaysia. Qual Life Res 2015 Sep 24;24(9):2297-2302. [doi: 10.1007/s11136-015-0969-8] [Medline: 25800728]

65. Fung CSC, Wan EYF, Yu CLY, Wong CKH. Validity and reliability of the 19-item Audit of Diabetes-Dependent Quality of Life (ADDQoL-19) questionnaire in Chinese patients with type 2 diabetes mellitus in primary care. Qual Life Res 2016 Sep 15;25(9):2373-2378. [doi: 10.1007/s11136-016-1263-0] [Medline: 26980420]

66. Abbatecola AM, Spazzafumo L, Fabbietti P, Testa R, Rabini RA, Bonfigli AR, et al. Diabetes-related quality of life is enhanced by glycaemic improvement in older people. Diabet Med 2015 Feb 05;32(2):243-249. [doi: 10.1111/dme.12605] [Medline: 25307368]

67. Soon SS, Goh SY, Bee YM, Poon JL, Li SC, Thumboo J, et al. Audit of Diabetes-Dependent Quality of Life (ADDQoL) [Chinese Version for Singapore] questionnaire: reliability and validity among Singaporeans with type 2 diabetes mellitus. Appl Health Econ Health Policy 2010;8(4):239-249. [doi: 10.2165/11313920-000000000-00000] [Medline: 20578779]

68. Kong D, Ding Y, Zuo X, Su W, Xiu L, Lin M, et al. Adaptation of the Audit of Diabetes-Dependent Quality of Life questionnaire to people with diabetes in China. Diabetes Res Clin Pract 2011 Oct;94(1):45-52. [doi: 10.1016/j.diabres.2011.05.026] [Medline: 21683467]

69. Lemon SC, Rosal MC, Welch G. Measuring quality of life in low-income, Spanish-speaking Puerto Ricans with type 2 diabetes residing in the mainland U.S. Qual Life Res 2011 Nov 8;20(9):1507-1511. [doi: 10.1007/s11136-011-9871-1] [Medline: 21384266]

70. Demirci H, Cinar Y, Bayram N, Bilgel N. Quality of life in type II diabetic patients in primary health care. Dan Med J 2012 Oct;59(10):A4468 [FREE Full text] [Medline: 23158887] 
71. Kamarul Imran M, Ismail AA, Naing L, Wan Mohamad WB. The reliability and validity of the Malay version of the 18-item audit of Diabetes Dependent Quality of Life (the Malay ADDQOL) questionnaire. Southeast Asian J Trop Med Public Health 2007 Mar;38(2):398-405. [Medline: 17539293]

72. Elasy TA, Samuel-Hodge CD, DeVellis RF, Skelly AH, Ammerman AS, Keyserling TC. Development of a health status measure for older African-American women with type 2 diabetes. Diabetes Care 2000 Mar 01;23(3):325-329. [doi: 10.2337/diacare.23.3.325]

73. Meadows KA, Abrams C, Sandbaek A. Adaptation of the Diabetes Health Profile (DHP-1) for use with patients with Type 2 diabetes mellitus: psychometric evaluation and cross-cultural comparison. Diabet Med 2000 Aug;17(8):572-580. [doi: 10.1046/j.1464-5491.2000.00322.x] [Medline: 11073178 ]

74. Mulhern B, Labeit A, Rowen D, Knowles E, Meadows K, Elliott J, et al. Developing preference-based measures for diabetes: DHP-3D and DHP-5D. Diabet Med 2017 Sep 01;34(9):1264-1275. [doi: 10.1111/dme.13377] [Medline: 28477411]

75. Li J, Li Z, Zhao W, Pan H, Halloran EJ. The reliability and validity of the diabetes care profile for Chinese populations. Eval Health Prof 2015 Jun 28;38(2):200-218. [doi: 10.1177/0163278714525628] [Medline: 24586109]

76. Li T, Lin C, Liu C, Li C, Lee Y. Validation of the Chinese version of the diabetes impact measurement scales amongst people suffering from diabetes. Qual Life Res 2006 Dec 7;15(10):1613-1619. [doi: 10.1007/s11136-006-0024-x] [Medline: $16826434]$

77. Talbot F, Nouwen A, Gingras J, Gosselin M, Audet J. The assessment of diabetes-related cognitive and social factors: the Multidimensional Diabetes Questionnaire. J Behav Med 1997;20:291-312. [doi: 10.1037/t66308-000]

78. Pawar S, Thakurdesai P. Translation and validation of hindi version of the multidimensional questionnaire (MDQ) for quality of life assessment in type 2 diabetes mellitus patients in indian population. International Journal of Pharmaceutical Sciences and Research 2013;4:1827-1832 [FREE Full text]

79. Kolawole B, Abodunde O, Ikem R, Fabiyi A. A Test of the reliability and validity of a diabetes specific quality of life scale in a Nigerian hospital. Qual Life Res 2004 Sep;13(7):1287-1295. [doi: 10.1023/b:qure.0000037483.85545.5f]

80. Speight J, Khagram L, Davies M. Generic and diabetes-specific well-being in the AT.LANTUS Follow-on study: further psychometric validation of the W-BQ28 indicates its utility in research and clinical practice in Type 2 diabetes in the UK. Diabet Med 2012 Sep;29(9):e345-e353. [doi: 10.1111/j.1464-5491.2012.03702.x] [Medline: 22540936]

81. Hajos TRS, Pouwer F, Skovlund SE, Den Oudsten BL, Geelhoed-Duijvestijn PHLM, Tack CJ, et al. Psychometric and screening properties of the WHO-5 well-being index in adult outpatients with Type 1 or Type 2 diabetes mellitus. Diabet Med 2013 Feb 21;30(2):e63-e69. [doi: 10.1111/dme.12040] [Medline: 23072401]

82. Cichoń E, Kiejna A, Kokoszka A, Gondek T, Rajba B, Lloyd CE, et al. Validation of the Polish version of WHO-5 as a screening instrument for depression in adults with diabetes. Diabetes Res Clin Pract 2020 Jan;159:107970. [doi: 10.1016/j.diabres.2019.107970] [Medline: 31805355]

83. Rankin SH, Galbraith ME, Johnson S. Reliability and validity data for a Chinese translation of the Center for Epidemiological Studies-Depression. Psychol Rep 1993 Dec 06;73(3 Pt 2):1291-1298. [doi: 10.2466/pr0.1993.73.3f.1291] [Medline: 8115582]

84. McHale M, Hendrikz J, Dann F, Kenardy J. Screening for depression in patients with diabetes mellitus. Psychosom Med 2008;70:869-874. [doi: 10.1097/psy.0b013e318186dea9]

85. Zhang Y, Ting RZW, Lam MHB, Lam S, Yeung RO, Nan H, et al. Measuring depression with CES-D in Chinese patients with type 2 diabetes: the validity and its comparison to PHQ-9. BMC Psychiatry 2015 Aug 18;15(1):198 [FREE Full text] [doi: 10.1186/s12888-015-0580-0] [Medline: 26281832]

86. Carter J, Cogo-Moreira H, Herrmann N, Merino D, Yang P, Shah BR, et al. Validity of the Center for Epidemiological Studies Depression scale in Type 2 diabetes. J Psychosom Res 2016 Nov;90:91-97. [doi: 10.1016/j.jpsychores.2016.09.013] [Medline: 27772565]

87. Kokoszka A. Depression in Diabetes Self-Rating Scale: A screening tool. Diabetologia Doswiadczalna i Kliniczna 2008;8:A43-A47 [FREE Full text]

88. de Cock ES, Emons WH, Nefs G, Pop VJ, Pouwer F. Dimensionality and scale properties of the Edinburgh Depression Scale (EDS) in patients with type 2 diabetes mellitus: the DiaDDzoB study. BMC Psychiatry 2011 Aug 24;11(1). [doi: 10.1186/1471-244x-11-141]

89. Zauszniewski JA, Chung C, Krafcik K, Sousa VD. Psychometric testing of the Depressive Cognition Scale in women with type 2 diabetes. J Nurs Meas 2001 May 01;9(1):61-72. [doi: 10.1891/1061-3749.9.1.61]

90. Hsu L, Kao C, Wang M, Chang C, Tsai P. Psychometric testing of a Mandarin Chinese version of the Clinically Useful Depression Outcome Scale for patients diagnosed with type 2 diabetes mellitus. Int J Nurs Stud 2014 Dec;51(12):1595-1604. [doi: 10.1016/j.ijnurstu.2014.05.004] [Medline: 24951085]

91. Zhang Y, Ting R, Lam M, Lam J, Nan H, Yeung R, et al. Measuring depressive symptoms using the Patient Health Questionnaire-9 in Hong Kong Chinese subjects with type 2 diabetes. J Affect Disord 2013 Nov;151(2):660-666. [doi: 10.1016/j.jad.2013.07.014] [Medline: 23938133]

92. Janssen EPCJ, Köhler S, Stehouwer CDA, Schaper NC, Dagnelie PC, Sep SJS, et al. The Patient Health Questionnaire-9 as a screening tool for depression in individuals with type 2 diabetes mellitus: the Maastricht Study. J Am Geriatr Soc 2016 Nov 26;64(11):e201-e206. [doi: 10.1111/jgs.14388] [Medline: 27783384] 
93. Udedi M, Muula AS, Stewart RC, Pence BW. The validity of the Patient Health Questionnaire-9 to screen for depression in patients with type-2 diabetes mellitus in non-communicable diseases clinics in Malawi. BMC Psychiatry 2019 Feb 27;19(1):81 [FREE Full text] [doi: 10.1186/s12888-019-2062-2] [Medline: 30813922]

94. Lupascu N, Timar B, Albai A, Roman D, Potre O, Timar R. Validation and cross-cultural adaptation of the depression Patient's Health Questionnaire - 9 in the Romanian population of patients with Type 2 Diabetes Mellitus. DMSO 2019 May;12:841-849. [doi: 10.2147/dmso.s203099]

95. Ting RZW, Nan H, Yu MWM, Kong APS, Ma RCW, Wong RYM, et al. Diabetes-related distress and physical and psychological health in chinese type 2 diabetic patients. Diabetes Care 2011 May 11;34(5):1094-1096 [FREE Full text] [doi: 10.2337/dc10-1612] [Medline: 21398526]

96. Farm BAS, Perwitasari DA, Thobari JA, Cao Q, Krabbe PF, Postma MJ. Translation, revision, and validation of the Diabetes Distress Scale for Indonesian type 2 diabetic outpatients with various types of complications. Value Health Reg Issues 2017 May;12:63-73. [doi: 10.1016/j.vhri.2017.03.010] [Medline: 28648318]

97. Venkataraman K, Tan LSM, Bautista DCT, Griva K, Zuniga YLM, Amir M, et al. Psychometric properties of the Problem Areas in Diabetes (PAID) instrument in Singapore. PLoS One 2015 Sep 3;10(9):e0136759 [FREE Full text] [doi: 10.1371/journal.pone.0136759] [Medline: 26336088]

98. Jannoo Z, Yap BW, Khan NM, Farcomeni A. Assessing diabetes distress among type 2 diabetes mellitus in Malaysia using the problem areas in diabetes scale. Value Health Reg Issues 2019 May;18:159-164. [doi: 10.1016/j.vhri.2019.03.004] [Medline: $\underline{\text { 31082796] }}$

99. Gross CC, Scain SF, Scheffel R, Gross JL, Hutz CS. Brazilian version of the Problem Areas in Diabetes Scale (B-PAID): validation and identification of individuals at high risk for emotional distress. Diabetes Res Clin Pract 2007 Jun;76(3):455-459. [doi: 10.1016/j.diabres.2006.09.022] [Medline: 17081645]

100. Eom YS, Park HS, Kim S, Yang SM, Nam MS, Lee HW, et al. Evaluation of stress in Korean patients with diabetes mellitus using the problem areas in diabetes-Korea questionnaire. Diabetes Metab J 2011 Apr;35(2):182-187 [FREE Full text] [doi: 10.4093/dmj.2011.35.2.182] [Medline: 21738901]

101. Lee E, Lee YW, Lee K, Kim YS, Nam M. Measurement of diabetes-related emotional distress using the Problem Areas in Diabetes scale: psychometric evaluations show that the short form is better than the full form. Health Qual Life Outcomes 2014 Oct 29;12(1):142 [FREE Full text] [doi: 10.1186/s12955-014-0142-z] [Medline: 25358396]

102. Huis In 't Veld EMJ, Makine C, Nouwen A, Karşıdağ, Kadıŏ̆lu P, Karşıdağ K, et al. Validation of the Turkish version of the problem areas in diabetes scale. Cardiovasc Psychiatry Neurol 2011 Dec 13;2011:315068-315066 [FREE Full text] [doi: 10.1155/2011/315068] [Medline: 22195273]

103. Papathanasiou A, Koutsovasilis A, Shea S, Philalithis A, Papavasiliou S, Melidonis A, et al. The Problem Areas in Diabetes (PAID) scale: psychometric evaluation survey in a Greek sample with type 2 diabetes. J Psychiatr Ment Health Nurs 2014 May 17;21(4):345-353. [doi: 10.1111/j.1365-2850.2012.01875.x] [Medline: 22340071]

104. Siaw M, Tai B, Lee J. Psychometric properties of the Chinese version of Problem Areas In Diabetes Scale (Sg-Paid-C) among high-risk polypharmacy patients with uncontrolled type 2 diabetes In Singapore. Value in Health 2016 Nov;19(7):A901. [doi: 10.1016/j.jval.2016.08.207]

105. Welch G, Schwartz CE, Santiago-Kelly P, Garb J, Shayne R, Bode R. Disease-related emotional distress of Hispanic and non-Hispanic type 2 diabetes patients. Ethn Dis 2007;17(3):541-547. [Medline: 17985511]

106. Arzaghi SM, Mahjouri MY, Heshmat R, Khashayar P, Larijani B. Psychometric properties of the Iranian version of the Problem Areas in Diabetes scale (IR-PAID-20). J Diabetes Metab Disord 2011;10:16 [FREE Full text]

107. Bijl J, Poelgeest-Eeltink A, Shortridge-Baggett L. The psychometric properties of the diabetes management self-efficacy scale for patients with type 2 diabetes mellitus. J Adv Nurs 1999 Aug;30(2):352-359. [doi: 10.1046/j.1365-2648.1999.01077.x] [Medline: 10457237]

108. Azami G, Kim Lam S, Shariff-Ghazali S, Mohd Said S, Aazami S, Mozafari M. Predictors of diabetes self-management behaviors in type 2 diabetes patients. IJDO 2021 Jan 16. [doi: $\underline{10.18502 / i j d o . v 12 i 4.5180]}$

109. Sturt J, Hearnshaw H, Wakelin M. Validity and reliability of the DMSES UK: a measure of self-efficacy for type 2 diabetes self-management. Prim Health Care 2010 Jun 22;11(04):374-381. [doi: 10.1017/s1463423610000101]

110. Lee E, van der Bijl J, Shortridge-Baggett LM, Han SJ, Moon SH. Psychometric properties of the Diabetes Management Self-Efficacy Scale in Korean patients with type 2 diabetes. Int J Endocrinol 2015;2015:780701 [FREE Full text] [doi: 10.1155/2015/780701] [Medline: 26089892]

111. Fappa E, Efthymiou V, Landis G, Rentoumis A, Doupis J. Validation of the Greek version of the Diabetes Management Self-Efficacy Scale (GR-DMSES). Adv Ther 2016 Jan 21;33(1):82-95. [doi: 10.1007/s12325-015-0278-1]

112. Pace AE, Gomes LC, Bertolin DC, Loureiro HMAM, Bijl JVD, Shortridge-Baggett LM. Adaptation and validation of the Diabetes Management Self-Efficacy Scale to Brazilian Portuguese. Rev Latino-Am Enfermagem 2017;25. [doi: 10.1590/1518-8345.1543.2861]

113. Messina R, Rucci P, Sturt J, Mancini T, Fantini MP. Assessing self-efficacy in type 2 diabetes management: validation of the Italian version of the Diabetes Management Self-Efficacy Scale (IT-DMSES). Health Qual Life Outcomes 2018 Apr 23;16(1):71 [FREE Full text] [doi: 10.1186/s12955-018-0901-3] [Medline: 29685153] 
114. Thojampa S. Psychometric evaluation of the Thai translation of the Self-Efficacy for Diabetes Scale in delaying the progress of diabetic nephropathy in adults with T2DM. Int J Afr Nurs Sci 2018;9:1-3. [doi: 10.1016/j.ijans.2018.05.006]

115. Zheng J, Wang Y, Ye X, Xiao L, Ye J, Li X, et al. Validation of diabetes medication self-efficacy scale in Chinese with type 2 diabetes. Patient Prefer Adherence 2018 Nov; Volume 12:2517-2525. [doi: 10.2147/ppa.s170144]

116. Sousa V, Hartman S, Miller E, Carroll M. New measures of diabetes self-care agency, diabetes self-efficacy, and diabetes self-management for insulin-treated individuals with type 2 diabetes. J Clin Nurs 2009 May;18(9):1305-1312. [doi: 10.1111/j.1365-2702.2008.02729.x] [Medline: 19413558]

117. Chang SJ, Song M, Im E. Psychometric evaluation of the Korean version of the Diabetes Self-efficacy Scale among South Korean older adults with type 2 diabetes. J Clin Nurs 2014 Aug 22;23(15-16):2121-2130. [doi: 10.1111/jocn.12133] [Medline: 23876167]

118. van der Heijden MMP, Pouwer F, Pop VJM. Psychometric properties of the Exercise Self-efficacy Scale in Dutch Primary care patients with type 2 diabetes mellitus. Int J Behav Med 2014 Apr 3;21(2):394-401. [doi: 10.1007/s12529-013-9308-z] [Medline: 23550033]

119. Fain JA. Psychometric properties of the Spanish Version of the Diabetes Self-management Assessment Report Tool. Diabetes Educ 2007 Dec 07;33(5):827-832. [doi: 10.1177/0145721707308355] [Medline: 17925586]

120. Toobert DJ, Hampson SE, Glasgow RE. The summary of diabetes self-care activities measure: results from 7 studies and a revised scale. Diabetes Care 2000 Jul 01;23(7):943-950 [FREE Full text] [doi: 10.2337/diacare.23.7.943] [Medline: 10895844]

121. Kav S, Akman A, Dogan N, Tarakci Z, Bulut Y, Hanoglu Z. Turkish validity and reliability of the summary of diabetes self-care activities measure for patients with type 2 diabetes mellitus. J Clin Nurs 2010 Oct;19(19-20):2933-2935. [doi: 10.1111/j.1365-2702.2010.03329.x] [Medline: 20846234]

122. Kamradt M, Bozorgmehr K, Krisam J, Freund T, Kiel M, Qreini M, et al. Assessing self-management in patients with diabetes mellitus type 2 in Germany: validation of a German version of the Summary of Diabetes Self-Care Activities measure (SDSCA-G). Health Qual Life Outcomes 2014 Dec 18;12(1):185 [FREE Full text] [doi: 10.1186/s12955-014-0185-1] [Medline: 25519204]

123. Adarmouch L, Sebbani M, Elyacoubi A, Amine M. Psychometric properties of a Moroccan version of the Summary of Diabetes Self-Care Activities Measure. J Diabetes Res 2016;2016:5479216-5479216 [FREE Full text] [doi: 10.1155/2016/5479216] [Medline: 27019853]

124. Sukkarieh-Haraty O, Howard E. Psychometric properties of the Arabic version of the Summary of Diabetes Self-Care Activities Instrument. Res Theory Nurs Pract 2016 Jan 01;30(1):60-69. [doi: 10.1891/1541-6577.30.1.60] [Medline: 27025000]

125. Choi EJ, Nam M, Kim SH, Park CG, Toobert DJ, Yoo JS, et al. Psychometric properties of a Korean version of the summary of diabetes self-care activities measure. Int J Nurs Stud 2011 Mar;48(3):333-337. [doi: 10.1016/j.ijnurstu.2010.08.007] [Medline: 20950807]

126. Mendonça SCBD, Zanetti ML, Sawada NO, Barreto IDDC, Andrade JSD, Otero LM. Construction and validation of the Self-care Assessment Instrument for patients with type 2 diabetes mellitus. Rev Lat Am Enfermagem 2017 Jun 05;25:e2890 [FREE Full text] [doi: 10.1590/1518-8345.1533.2890] [Medline: 28591298]

127. Khagram L, Martin CR, Davies MJ, Speight J. Psychometric validation of the Self-Care Inventory-Revised (SCI-R) in UK adults with type 2 diabetes using data from the AT.LANTUS Follow-on study. Health Qual Life Outcomes 2013 Feb 26;11(1):24 [FREE Full text] [doi: 10.1186/1477-7525-11-24] [Medline: 23443007]

128. García AA. The Diabetes Symptom Self-Care Inventory: development and psychometric testing with Mexican Americans. J Pain Symptom Manage 2011 Apr;41(4):715-727 [FRE Full text] [doi: 10.1016/j.jpainsymman.2010.06.018] [Medline: 21276705]

129. McCaskill GM, Bolland KA, Burgio KL, Leeper J. Development and validation of a diabetes self-management instrument for older African-Americans. Soc Work Health Care 2016 Apr 04;55(5):381-394. [doi: 10.1080/00981389.2015.1129012] [Medline: 27045578]

130. Nakawatase Y, Taru C, Tsutou A, Shiotani H, Kido Y, Ohara T, et al. Development of an evaluation scale for self-management behavior related to physical activity of type 2 diabetic patients. Diabetes Care 2007 Nov 20;30(11):2843-2848. [doi: 10.2337/dc07-0685] [Medline: 17644618]

131. Thojampa S, Mawn B. Psychometric evaluation of the Thai translation of the Diabetes Self-management Questionnaire in type 2 diabetes. Int J Nurs Sci 2017 Jul 10;4(3):236-238 [FREE Full text] [doi: 10.1016/j.ijnss.2017.06.006] [Medline: 31406746]

132. Bukhsh A, Lee SWH, Pusparajah P, Schmitt A, Khan TM. Psychometric properties of the Diabetes Self-Management Questionnaire (DSMQ) in Urdu. Health Qual Life Outcomes 2017 Oct 12;15(1):200 [FREE Full text] [doi: 10.1186/s12955-017-0776-8] [Medline: 29025432]

133. Dao-Tran T, Anderson DJ, Chang AM, Seib C, Hurst C. Vietnamese version of Diabetes Self-Management Instrument: development and psychometric testing. Res Nurs Health 2017 Apr 09;40(2):177-184. [doi: 10.1002/nur.21777] [Medline: 27933635] 
134. Lee C, Lin C, Anderson R. Psychometric evaluation of the Diabetes Self-Management Instrument Short Form (DSMI-20). Appl Nurs Res 2016 Feb;29:83-88. [doi: 10.1016/j.apnr.2015.04.013] [Medline: 26856494]

135. Seo K, Song M, Choi S, Kim S, Chang SJ. Development of a scale to measure diabetes self-management behaviors among older Koreans with type 2 diabetes, based on the seven domains identified by the American Association of Diabetes Educators. Jpn J Nurs Sci 2017 Apr 13;14(2):161-170. [doi: 10.1111/jins.12145] [Medline: 27734627]

136. Peyrot M, Bushnell DM, Best JH, Martin ML, Cameron A, Patrick DL. Development and validation of the self-management profile for type 2 diabetes (SMP-T2D). Health Qual Life Outcomes 2012 Oct 05;10(1):125 [FREE Full text] [doi: 10.1186/1477-7525-10-125] [Medline: 23039868]

137. Laranjo L, Dias V, Nunes C, Paiva D, Mahoney B. Translation and validation of the Patient Activation Measure in Portuguese people with type 2 diabetes Mellitus. Acta Med Port 2018 Aug 31;31(7-8):382-390 [FREE Full text] [doi: 10.20344/amp.9072] [Medline: $\underline{30189166]}$

138. Chernyak N, Jülich F, Kasperidus J, Stephan A, Begun A, Kaltheuner M, et al. Time cost of diabetes: development of a questionnaire to assess time spent on diabetes self-care. J Diabetes Complications 2017 Jan;31(1):260-266. [doi: 10.1016/j.jdiacomp.2016.06.016] [Medline: 27411888]

139. Manit A, Tuicomepee A, Jiamjarasrangsi W, Taneepanichskul S. Development of needs and resources for self-management assessment instrument in Thais with type 2 diabetes: cross-cultural adaptation. J Med Assoc Thai 2011 Nov;94(11):1304-1313. [Medline: 22256469]

140. Mahjouri MY, Arzaghi SM, Heshmat R, Khashayar P, Esfahani EN, Larijani B. Psychometric properties of the Iranian version of Diabetes Empowerment Scale (IR-DES-28). J Diabetes Metab Disord 2012 Aug 02;11(1):4 [FREE Full text] [doi: 10.1186/2251-6581-11-4] [Medline: 23497711$]$

141. Hara Y, Iwashita S, Okada A, Tajiri Y, Nakayama H, Kato T, et al. Development of a novel, short, self-completed questionnaire on empowerment for patients with type 2 diabetes mellitus and an analysis of factors affecting patient empowerment. Biopsychosoc Med 2014;8(1):19 [REE Full text] [doi: 10.1186/1751-0759-8-19] [Medline: 25183994]

142. Ching SM, Yee A, Lee PY, Ramachandran V, Shum KM, Ismael NF, et al. Psychometric properties of the Malay version of the diabetes empowerment scale among hospital Serdang type 2 diabetes mellitus patients using exploratory factor analysis. Health Qual Life Outcomes 2020 Feb 07;18(1):23 [FREE Full text] [doi: 10.1186/s12955-020-1280-0] [Medline: 32033609]

143. Chaves FF, Reis IA, Pagano AS, Torres HDC. Translation, cross-cultural adaptation and validation of the Diabetes Empowerment Scale - Short Form. Rev Saúde Pública 2017;51. [doi: 10.1590/s1518-8787.2017051006336]

144. Sousa M, Almeida M, Loureiro H, Martins T. Study of the psychometric properties of the Diabetes Empowerment Scale Short Form (DES-SF). Port J Public Health 2019 Nov 29;37(2-3):66-72. [doi: 10.1159/000504629]

145. Saffari M, Karimi T, Koenig HG, Al-Zaben F. Psychometric evaluation of the Persian version of the Type 2 Diabetes and Health Promotion Scale (T2DHPS): a diabetes-specific measure of lifestyle. Scand J Caring Sci 2015 Sep 18;29(3):603-612. [doi: 10.1111/scs.12181] [Medline: 25236973]

146. Yildiz E, Kavuran E. The validity and reliability of the type 2 diabetes and health promotion scale Turkish version: a methodological study. Scand J Caring Sci 2018 Mar 22;32(1):417-421. [doi: 10.1111/scs.12483] [Medline: 28833366]

147. Wang R, Lin L, Cheng C, Hsu M, Kao C. The psychometric testing of the diabetes health promotion self-care scale. J Nurs Res 2012 Jun;20(2):122-130. [doi: 10.1097/jnr.0b013e318254eb47] [Medline: 22592107]

148. Akohoue SA, Wallston KA, Schlundt DG, Rothman RL. Psychometric evaluation of the short version of the Personal Diabetes Questionnaire to assess dietary behaviors and exercise in patients with type 2 diabetes. Eating Behaviors 2017 Aug;26:182-188. [doi: 10.1016/j.eatbeh.2017.04.002]

149. Cheng L, Leung DYP, Wu Y, Sit JWH, Yang M, Li X. Psychometric properties of the Modified Personal Diabetes Questionnaire among Chinese patients with type 2 diabetes. Eval Health Prof 2018 Mar 20;41(1):3-24. [doi: 10.1177/0163278716664393] [Medline: 27649714]

150. Lewis K, Jennings A, Ward J, Bradley C. Health belief scales developed specifically for people with tablet-treated type 2 diabetes. Diabet Med 1990 Feb;7(2):148-155. [doi: 10.1111/j.1464-5491.1990.tb01350.x] [Medline: 2137756]

151. Brown SA, Becker HA, Garcia AA, Barton SA, Hanis CL. Measuring health beliefs in Spanish-speaking Mexican Americans with type 2 diabetes: adapting an existing instrument. Res Nurs Health 2002 Apr 14;25(2):145-158. [doi: 10.1002/nur.10023] [Medline: 11933008$]$

152. Kartal A, Ozsoy SA. Validity and reliability study of the Turkish version of Health Belief Model Scale in diabetic patients. Int J Nurs Stud 2007 Nov;44(8):1447-1458. [doi: 10.1016/j.ijnurstu.2007.06.004] [Medline: 17655849]

153. Lujan J. Testing the diabetes knowledge and health beliefs of Mexican Americans on the Texas-Mexico border. Hisp Hlth Care Int 2008 Mar 01;6(1):9-20. [doi: 10.1891/1540-4153.6.1.9]

154. Gerber B, Smith Jr EV, Girotti M, Pelaez L, Lawless K, Smolin L, et al. Using Rasch measurement to investigate the cross-form equivalence and clinical utility of Spanish and English versions of a diabetes questionnaire: a pilot study. $\mathbf{J}$ Appl Meas 2002;3(3):243-271. [Medline: 12147912]

155. Padhy M, Padiri RA, Hariharan M, Rana S. Diabetes Mellitus Knowledge Test: development, psychometric evaluation, and establishing norms for Indian population. Int J Diabetes Dev Ctries 2018 May 7;39(1):206-217. [doi:

10.1007/s13410-018-0644-z] 
156. Matin H, Nadrian H, Sarbakhsh P, Shaghaghi A. Factorial structure and psychometric analysis of the Persian version of Perceived Competence Scale for Diabetes (PCSD-P). Behav Sci (Basel) 2019 May 07;9(5):50 [FREE Full text] [doi: 10.3390/bs9050050] [Medline: 31067721]

157. Miller CK, Achterberg CL. Reliability and validity of a nutrition and food-label knowledge test for women with Type 2 diabetes mellitus. J Nutr Educ 2000 Jan;32(1):43-48. [doi: 10.1016/s0022-3182(00)70509-7]

158. Miller C, Edwards L. Development and validation of a shelf inventory to evaluate household food purchases among older adults with diabetes mellitus. J Nutr Educ Behav 2002 Sep;34(5):261-267. [doi: 10.1016/s1499-4046(06)60104-8]

159. Samuel-Hodge CD, DeVellis RF, Ammerman A, Keyserling TC, Elasy TA. Reliability and validity of a measure of perceived diabetes and dietary competence in African American women with type 2 diabetes. Diabetes Educ 2002 Sep 04;28(6):979-988. [doi: 10.1177/014572170202800612] [Medline: 12526638]

160. Han CY, Zheng X, Lee LF, Chan CG, Lee YQ, Zailani NA, et al. Development of a diabetes-related nutrition knowledge questionnaire for individuals with type 2 diabetes mellitus in Singapore. Nutr Diet 2019 Nov 31;76(5):567-573. [doi: 10.1111/1747-0080.12513] [Medline: 30706657]

161. Finbråten HS, Guttersrud, Nordström G, Pettersen KS, Trollvik A, Wilde-Larsson B. Validating the Functional, Communicative, and Critical Health Literacy Scale using Rasch modeling and confirmatory factor analysis. J Nurs Meas 2018 Aug 01;26(2):341-363. [doi: 10.1891/1061-3749.26.2.341] [Medline: 30567948]

162. Kang SJ, Sim KH, Song BR, Park J, Chang SJ, Park C, et al. Validation of the health literacy scale for diabetes as a criterion-referenced test with standard setting procedures. Patient Educ Couns 2018 Aug;101(8):1468-1476. [doi: 10.1016/j.pec.2018.03.013] [Medline: 29598965]

163. Lee E, Lee YW. First-order vs. second-order structural validity of the Health Literacy Scale in patients with diabetes. Scand J Caring Sci 2018 Mar 03;32(1):441-447. [doi: 10.1111/scs.12460] [Medline: 28771769]

164. Luo H, Patil SP, Wu Q, Bell RA, Cummings DM, Adams AD, et al. Validation of a combined health literacy and numeracy instrument for patients with type 2 diabetes. Patient Educ Couns 2018 Oct;101(10):1846-1851. [doi: 10.1016/j.pec.2018.05.017] [Medline: 29805071]

165. Ashok KM, Shanmugasundaram P. Development of a validated questionnaire to assess knowledge and awareness among uncontrolled diabetic patients toward diabetes mellitus. Drug Invent Today 2019;11:801-806 [FREE Full text]

166. Ashok Kumar M, Shanmugasundaram P. A validation study of questionnaire towards mobile based health applications in uncontrolled diabetic population of India (South). Diabetes Metab Syndr 2019 May;13(3):2106-2110. [doi:

10.1016/j.dsx.2019.04.037] [Medline: 31235144]

167. Finbråten HS, Pettersen KS, Wilde-Larsson B, Nordström G, Trollvik A, Guttersrud. Validating the European Health Literacy Survey Questionnaire in people with type 2 diabetes: latent trait analyses applying multidimensional Rasch modelling and confirmatory factor analysis. J Adv Nurs 2017 Nov 29;73(11):2730-2744. [doi: 10.1111/jan.13342] [Medline: 28543754]

168. Moock J, Hessel F, Ziegeler D, Kubiak T, Kohlmann T. Development and testing of the Insulin Treatment Experience Questionnaire (ITEQ). Patient 2010 Mar 01;3(1):45-58. [doi: 10.2165/11319510-000000000-00000] [Medline: 22273275]

169. Ishii H, Shin H, Tosaki T, Haga T, Nakajima Y, Shiraiwa T, et al. Reproducibility and validity of a questionnaire measuring treatment burden on patients with type 2 diabetes: Diabetic Treatment Burden Questionnaire (DTBQ). Diabetes Ther 2018 Jun 29;9(3):1001-1019 [FREE Full text] [doi: 10.1007/s13300-018-0414-4] [Medline: 29600503]

170. Rubin RR, Peyrot M. Psychometric properties of an instrument for assessing the experience of patients treated with inhaled insulin: the inhaled insulin treatment questionnaire (IITQ). Health Qual Life Outcomes 2010 Mar 24;8(1):32 [FREE Full text] [doi: 10.1186/1477-7525-8-32] [Medline: 20334647]

171. Kontodimopoulos N, Arvanitaki E, Aletras VH, Niakas D. Psychometric properties of the Greek Diabetes Treatment Satisfaction Questionnaire. Health Qual Life Outcomes 2012 Feb 01;10(1):17 [FREE Full text] [doi: 10.1186/1477-7525-10-17] [Medline: 22296783]

172. Brod M, Christensen T, Kongs $\emptyset$ JH, Bushnell DM. Examining and interpreting responsiveness of the Diabetes Medication Satisfaction measure. J Med Econ 2009 Oct 08;12(4):309-316. [doi: 10.3111/13696990903337017] [Medline: 19811109]

173. Snoek FJ, Skovlund SE, Pouwer F. Development and validation of the insulin treatment appraisal scale (ITAS) in patients with type 2 diabetes. Health Qual Life Outcomes 2007 Dec 20;5:69 [FREE Full text] [doi: 10.1186/1477-7525-5-69] [Medline: 18096074$]$

174. Lee KP. Translation and validation of the Insulin Treatment Appraisal Scale in Hong Kong primary care patients. J Diabetes Investig 2018 Mar;9(2):311-320 [FREE Full text] [doi: 10.1111/jdi.12704] [Medline: 28626953]

175. Saritas SC, Erci B, Sahin I, Timocin E. Validity study of the Turkish version of the barriers to insulin treatment questionnaire. Int J Diabetes Dev Ctries 2018 Aug 9;39(2):247-253. [doi: 10.1007/s13410-018-0670-x]

176. Fu SN, Chin WY, Wong CKH, Yeung VTF, Yiu MP, Tsui HY, et al. Development and validation of the Chinese Attitudes to Starting Insulin Questionnaire (Ch-ASIQ) for primary care patients with type 2 diabetes. PLoS One 2013 Nov 13;8(11):e78933 [FREE Full text] [doi: 10.1371/journal.pone.0078933] [Medline: 24236071]

177. Osborn CY, Gonzalez JS. Measuring insulin adherence among adults with type 2 diabetes. J Behav Med 2016 Aug 9;39(4):633-641 [FREE Full text] [doi: 10.1007/s10865-016-9741-y] [Medline: 27062271] 
178. Pedrosa RBDS, Trevisan DD, Nascimento RAD, São-João TM, Lima MHDM, Rodrigues RCM. Psychometric performance of the Brazilian version the "Insulin Management Diabetes Self-Efficacy Scale" for patients with type 2 diabetes mellitus. Article in Portuguese. Medicina (Ribeirao Preto) 2018 Nov 22;51(2):121-130. [doi: 10.11606/issn.2176-7262.v51i2p121-130]

179. Anderson R, Skovlund S, Marrero D, Levine D, Meadows K, Brod M, et al. Development and validation of the Insulin Treatment Satisfaction Questionnaire. Clin Ther 2004;26:565-578. [doi: 10.1037/t68803-000]

180. Ishii H, Oda E. Reproducibility and validity of a satisfaction questionnaire on hypoglycemic agents: the Oral Hypoglycemic Agent Questionnaire (OHA-Q). Diabetol Int 2012 Aug 1;3(3):152-163. [doi: 10.1007/s13340-012-0074-y]

181. Peyrot M, Harshaw Q, Shillington A, Xu Y, Rubin R. Validation of a tool to assess medication treatment satisfaction in patients with Type 2 diabetes: the Diabetes Medication System Rating Questionnaire (DMSRQ). Diabet Med 2012;29:1060-1066. [doi: 10.1111/j.1464-5491.2011.03538.x]

182. Demirtaş A, Akbayrak N. Development of an assessment scale for treatment compliance in type 2 Diabetes Mellitus in Turkish population: psychometric evaluation. Int J Nurs Sci 2017 Jul 10;4(3):244-251 [FREE Full text] [doi: 10.1016/j.ijnss.2017.06.002] [Medline: 31406748]

183. Sakthong P, Chabunthom R, Charoenvisuthiwongs R. Psychometric properties of the Thai version of the 8-item Morisky Medication Adherence Scale in patients with type 2 diabetes. Ann Pharmacother 2009 Apr 14;43(5):950-957. [doi: 10.1345/aph.11453]

184. Wang Y, Lee J, Toh M, Tang W, Ko Y. Validity and reliability of a self-reported measure of medication adherence in patients with Type 2 diabetes mellitus in Singapore. Diabet Med 2012 Sep;29(9):e338-e344. [doi: 10.1111/j.1464-5491.2012.03733.x] [Medline: 22672497]

185. Lee W, Ahn J, Kim J, Hong Y, Hong SK, Kim YT, et al. Reliability and validity of a self-reported measure of medication adherence in patients with type 2 diabetes mellitus in Korea. J Int Med Res 2013 Aug 16;41(4):1098-1110 [FREE Full text] [doi: 10.1177/0300060513484433] [Medline: 23860015]

186. Wang J, Bian R, Mo Y. Validation of the Chinese version of the eight-item Morisky medication adherence scale in patients with type 2 diabetes mellitus. J Clin Gerontol Geriatr 2013 Dec;4(4):119-122. [doi: 10.1016/j.jcgg.2013.06.002]

187. Zongo A, Guénette L, Moisan J, Grégoire JP. Predictive validity of self-reported measures of adherence to noninsulin antidiabetes medication against control of glycated hemoglobin levels. Can J Diabetes 2016 Feb;40(1):58-65. [doi: 10.1016/j.jcjd.2015.06.008] [Medline: 26507401]

188. Zongo A, Guénette L, Moisan J, Guillaumie L, Lauzier S, Grégoire JP. Revisiting the internal consistency and factorial validity of the 8-item Morisky Medication Adherence Scale. SAGE Open Med 2016;4:2050312116674850 [FREE Full text] [doi: 10.1177/2050312116674850] [Medline: 27895914]

189. Kristina SA, Putri LR, Riani DA, Ikawati Z, Endarti D. Validity of self-reported measure of medication adherence among diabetic patients in Indonesia. Int Res J Pharm 2019 Aug 2;10(7):144-148. [doi: 10.7897/2230-8407.1007234]

190. Prado-Aguilar CA, Martínez YV, Segovia-Bernal Y, Reyes-Martínez R, Arias-Ulloa R. Performance of two questionnaires to measure treatment adherence in patients with Type-2 diabetes. BMC Public Health 2009 Jan 26;9:38 [FREE Full text] [doi: 10.1186/1471-2458-9-38] [Medline: 19171059]

191. Fall E, Gauchet A, Izaute M, Horne R, Chakroun N. Validation of the French version of the Beliefs about Medicines Questionnaire (BMQ) among diabetes and HIV patients. Eur Rev Appl Psychol 2014 Nov;64(6):335-343. [doi: 10.1016/j.erap.2014.08.005]

192. Chung WW, Chua SS, Lai PSM, Morisky DE. The Malaysian Medication Adherence Scale (MALMAS): concurrent validity using a clinical measure among people with type 2 diabetes in Malaysia. PLoS One 2015 Apr 24;10(4):e0124275 [FREE Full text] [doi: 10.1371/journal.pone.0124275] [Medline: 25909363]

193. Boas LCG, Lima MLSAPD, Pace AE. Adherence to treatment for diabetes mellitus: validation of instruments for oral antidiabetics and insulin. Rev Lat Am Enfermagem 2014 Jan;22(1):11-18 [FREE Full text] [doi: 10.1590/0104-1169.3155.2386] [Medline: 24553698]

194. Kim C, Park E, Schlenk EA, Kim M, Kim DJ. Psychometric evaluation of a Korean version of the Adherence to Refills and Medications Scale (ARMS) in adults with type 2 diabetes. Diabetes Educ 2016 Apr 22;42(2):188-198. [doi: 10.1177/0145721716632062] [Medline: 26902527]

195. Peyrot M, Xu Y, Rubin RR. Development and validation of the Diabetes Medication System Rating Questionnaire-Short Form. Diabet Med 2014 Oct 18;31(10):1237-1244 [FREE Full text] [doi: 10.1111/dme.12453] [Medline: 24673614]

196. Kawata AK, Wilson H, Ong SH, Kulich K, Coyne K. Development and psychometric evaluation of the Hypoglycemia Perspectives Questionnaire in patients with type 2 diabetes mellitus. Patient 2016 Oct 12;9(5):395-407. [doi: 10.1007/s40271-016-0163-2] [Medline: 26970976]

197. Çinar D, Yava A. Validity and reliability of functional assessment of chronic illness treatment-fatigue scale in Turkish patients with type 2 diabetes. Endocrinol Diabetes Nutr (Engl Ed) 2018 Aug;65(7):409-417. [doi: 10.1016/j.endinu.2018.01.010] [Medline: 29685730]

198. de Mesa U, Anonuevo-Cruz MC, Nicodemus N, Reyes N. Development and validation of a questionnaire evaluating impaired hypoglycemia awareness among adult filipino patients with type 2 diabetes mellitus. J ASEAN Fed Endocr Soc 2017 Sep 30;32(2):158-164 [FREE Full text] [doi: 10.15605/jafes.032.02.10] [Medline: 33442100] 
199. Liu Y, Xiong S, Sang M, Li Y, Anarte Ortiz MT, Xing Q, et al. Reliability and validity of the Chinese version of the new fear of hypoglycemia scale: FH-15. Int J Nurs Sci 2018 Oct 10;5(4):343-351 [FREE Full text] [doi: 10.1016/j.ijnss.2018.09.008] [Medline: $\underline{31406846]}$

200. Lee E, Lee K, Song R, Snoek FJ, Moon S. Psychometric evaluation of the Korean version of the Diabetes Symptom Checklist-Revised (DSC-R) for patients with type 2 diabetes. Health Qual Life Outcomes 2014 May 19;12(1):77 [FREE Full text] [doi: 10.1186/1477-7525-12-77] [Medline: 24885358]

201. Arbuckle RA, Humphrey L, Vardeva K, Arondekar B, Danten-Viala M, Scott JA, et al. Psychometric evaluation of the Diabetes Symptom Checklist-Revised (DSC-R)--a measure of symptom distress. Value Health 2009 Nov;12(8):1168-1175 [FREE Full text] [doi: 10.1111/j.1524-4733.2009.00571.x] [Medline: 19558371 ]

202. Naegeli AN, Hayes C. A psychometric evaluation of the Diabetes Symptom Checklist-Revised (DSC-R) cognitive distress, fatigue, hyperglycemia, and hypoglycemia subscales in patients with type 1 and type 2 diabetes. DMSO 2010 Mar;Volume 3:27-30. [doi: 10.2147/dmso.s9465]

203. Sato E, Suzukamo Y, Miyashita M, Kazuma K. Development of a diabetes diet-related quality-of-life scale. Diabetes Care 2004 Jun 25;27(6):1271-1275. [doi: 10.2337/diacare.27.6.1271] [Medline: 15161774]

204. Sato E, Ochiai R, Shibayama T, Nishigaki M, Abe Y, Sawa T, et al. Reliability and validity of revised and short form versions of diabetes diet-related quality of life scale. Diabetol Int 2017 Jun;8(2):181-192 [FREE Full text] [doi: 10.1007/s13340-016-0291-x] [Medline: 30603320]

205. Hayes RP, DeLozier AM. Reliability, validity, and responsiveness of the Impact of Weight on Self-Perceptions Questionnaire (IW-SP) in individuals with type 2 diabetes and obesity. Diabetes Technol Ther 2015 Mar;17(3):210-214. [doi: 10.1089/dia.2014.0142] [Medline: 25353705]

206. Martín Payo R, González Méndez X, Papín Cano C, Suárez Álvarez J. Development and validation of a questionnaire for assessing the characteristics of diet and physical activity in patients with type 2 diabetes. Psicothema 2018 Feb;30(1):116-122. [doi: 10.7334/psicothema2017.269] [Medline: 29363480]

207. Rohani H, Eslami AA, Ghaderi A, Jafari-Koshki T, Sadeghi E, Bidkhori M, et al. Validation and psychometric evaluation of physical activity belief scale among patients with type 2 diabetes mellitus: an application of health action process approach. Health Promot Perspect 2016 Jun 11;6(2):71-79 [FREE Full text] [doi: 10.15171/hpp.2016.13] [Medline: 27386421]

208. Teng Y, Wang S, Wang N, Muhuyati. STOP-Bang questionnaire screening for obstructive sleep apnea among Chinese patients with type 2 diabetes mellitus. Arch Med Sci 2018 Aug;14(5):971-978 [FREE Full text] [doi:

10.5114/aoms.2018.73984] [Medline: 30154877 ]

209. Donovan LM, Yu L, Bertisch SM, Buysse DJ, Rueschman M, Patel SR. Responsiveness of patient-reported outcomes to treatment among patients with type 2 diabetes mellitus and OSA. Chest 2020 Mar;157(3):665-672 [FREE Full text] [doi: 10.1016/j.chest.2019.11.011] [Medline: $\underline{31785255]}$

210. Shakibazadeh E, Rashidian A, Larijani B, Shojaeezadeh D. Psychometric properties of the Iranian version of Resources and Support for Chronic Illness Self-management Scale in patients with type 2 diabetes. Int J Prev Med 2012 Feb;3(2):84-90 [FREE Full text] [Medline: 22347603]

211. Hara Y, Iwashita S, Ishii K, Inada C, Okada A, Tajiri Y, et al. The reliability and validity of the Japanese version of the Diabetes Family Behavior Checklist (DFBC) for assessing the relationship between type 2 diabetes mellitus patients and their families with respect to adherence to treatment regimen. Diabetes Res Clin Pract 2013 Jan;99(1):39-47. [doi: 10.1016/j.diabres.2012.10.014] [Medline: 23107110 ]

212. Littlewood K, Cummings DM, Lutes L, Solar C. Psychometric properties of the Family Support Scale adapted for African American women with type 2 diabetes mellitus. Ethn Dis 2015;25(2):193-199. [Medline: 26118148]

213. Matin H, Nadrian H, Dastjerdi L, Sarbakhsh P, Shaghaghi A. Psychometric properties of the Persian Health Care Climate Questionnaire (HCCQ-P): assessment of type 2 diabetes care supportiveness in Iran. PPA 2019 May;13:783-793. [doi: 10.2147/ppa.s201400]

214. Sofulu F, Unsalavdal RE, Arkan RB. Validity and reliability of the diabetes family support and conflict scale in Turkish. Acta Medica Mediterranea 2017;33:107-114. [doi: 10.19193/0393-6384_2017_1_017]

215. Kato A, Takada M, Hashimoto H. Reliability and validity of the Japanese version of the self-stigma scale in patients with type 2 diabetes. Health Qual Life Outcomes 2014 Dec 12;12(1):179 [FREE Full text] [doi: 10.1186/s12955-014-0179-z] [Medline: 25495723]

216. Koike M, Inagaki M, Tasaki K, Matsui K, Horiguchi T, Oda A, et al. Validation of the relationship consciousness of Japanese Patients with type 2 diabetes scale. Int J Nurs Sci 2019 Jan 10;6(1):31-37 [FREE Full text] [doi: 10.1016/j.ijnss.2018.09.007] [Medline: 31406866]

217. Hara Y, Koyama S, Morinaga T, Ito H, Kohno S, Hirai H, et al. The reliability and validity of the Japanese version of the Appraisal of Diabetes Scale for type 2 diabetes patients. Diabetes Res Clin Pract 2011 Jan;91(1):40-46. [doi: 10.1016/j.diabres.2010.09.034] [Medline: 21040993]

218. Browne JL, Ventura AD, Mosely K, Speight J. Measuring the stigma surrounding type 2 diabetes: development and validation of the type 2 Diabetes Stigma Assessment Scale (DSAS-2). Diabetes Care 2016 Dec 11;39(12):2141-2148. [doi: 10.2337/dc16-0117] [Medline: 27515964] 
219. Lee E, Lee YW, Lee K, Nam M, Kim YS, Han SJ. A Korean version of the Appraisal of Diabetes Scale (ADS-K): psychometric evaluation with a population of Koreans with type 2 diabetes. J Transcult Nurs 2015 May 29;26(3):270-278. [doi: 10.1177/1043659614524793] [Medline: 24782147]

220. Ebrahimi H, Karimi Moonaghi H, Asghari Jafarabadi M, Namdar Areshtanab H, Jouybari L. Development and preliminary validation of Diabetes Adjustment Assessment Scale (DAAS): a new measure of adjustment with type 2 diabetes. J Caring Sci 2016 Jun 01;5(2):145-152 [FREE Full text] [doi: 10.15171/jcs.2016.015] [Medline: 27354978]

221. Mahjouri MY, Arzaghi SM, Qorbani M, Esfahani EN, Larijani B. Evaluation of psychometric properties of the third version of the Iranian Diabetes Attitude Scale (IR-DAS-3). J Diabetes Metab Disord 2011;10:8 [FREE Full text]

222. Persson L, Erichsen M, Wändell P, Gåfvels C. Psychometric evaluation of a coping questionnaire in two independent samples of people with diabetes. Stress Health 2013 Oct 05;29(4):286-296. [doi: 10.1002/smi.2466] [Medline: 23125028]

223. Traina S, Mathias S, Colwell H, Crosby R, Abraham C. The Diabetes Intention, Attitude, and Behavior Questionnaire: evaluation of a brief questionnaire to measure physical activity, dietary control, maintenance of a healthy weight, and psychological antecedents. Patient Prefer Adherence 2016 Feb:213. [doi: 10.2147/ppa.s94878]

224. Martinez NC, Sousa VD. Cross-cultural validation and psychometric evaluation of the Spanish Brief Religious Coping Scale (S-BRCS). J Transcult Nurs 2011 Jul 19;22(3):248-256. [doi: 10.1177/1043659611404426] [Medline: 21505097]

225. Golin CE, DiMatteo MR, Leake B, Duan N, Gelberg L. A diabetes-specific measure of patient desire to participate in medical decision making. Diabetes Educ 2001 Sep 04;27(6):875-886. [doi: 10.1177/014572170102700613] [Medline: 12211927]

226. Hearnshaw H, Wright K, Dale J, Sturt J, Vermeire E, van Royen P. Development and validation of the Diabetes Obstacles Questionnaire (DOQ) to assess obstacles in living with Type 2 diabetes. Diabet Med 2007;24:878-882. [doi: 10.1111/j.1464-5491.2007.02137.x]

227. Vandekerckhove M, Vermeire E, Weeren A, Van Royen P. Validation of the Diabetes Obstacles Questionnaire (DOQ) to assess obstacles in living with type 2 diabetes in a Belgian population. Prim Care Diabetes 2009 Feb;3(1):43-47. [doi: 10.1016/j.pcd.2009.02.003] [Medline: 19264569 ]

228. Pilv L, Vermeire E, Rätsep A, Moreau A, Nikolić D, Petek D, et al. Development and validation of the short version of the diabetes obstacles questionnaire (DOQ-30) in six European countries. Eur J Gen Pract 2016 Nov 18;22(1):16-22. [doi: 10.3109/13814788.2015.1093619] [Medline: 26578192]

229. Hill-Briggs F, Yeh H, Gary TL, Batts-Turner M, D'Zurilla T, Brancati FL. Diabetes problem-solving scale development in an adult, African American sample. Diabetes Educ 2007 Nov 19;33(2):291-299. [doi: 10.1177/0145721707299267] [Medline: 17426304$]$

230. Egede LE, Ellis C. Development and psychometric properties of the 12-item diabetes fatalism scale. J Gen Intern Med 2010 Jan 12;25(1):61-66 [FRE Full text] [doi: 10.1007/s11606-009-1168-5] [Medline: 19908102]

231. Abubakari A, Jones MC, Lauder W, Kirk A, Devendra D, Anderson J. Psychometric properties of the Revised Illness Perception Questionnaire: factor structure and reliability among African-origin populations with type 2 diabetes. Int J Nurs Stud 2012 Jun;49(6):672-681. [doi: 10.1016/j.ijnurstu.2011.11.008] [Medline: 22142936]

232. Traina SB, Colwell HH, Crosby RD, Mathias SD. Pragmatic measurement of health satisfaction in people with type 2 diabetes mellitus using the Current Health Satisfaction Questionnaire. Patientt Relat Outcome Meas 2015 Mar:103. [doi: 10.2147/prom.s79368]

233. Chew B, Vos RC, Heijmans M, Shariff-Ghazali S, Fernandez A, Rutten GEHM. Validity and reliability of a Malay version of the brief illness perception questionnaire for patients with type 2 diabetes mellitus. BMC Med Res Methodol 2017 Aug 03;17(1):118 [FREE Full text] [doi: 10.1186/s12874-017-0394-5] [Medline: 28774271]

234. Liberati A, Altman DG, Tetzlaff J, Mulrow C, Gøtzsche PC, Ioannidis JPA, et al. The PRISMA statement for reporting systematic reviews and meta-analyses of studies that evaluate healthcare interventions: explanation and elaboration. BMJ 2009 Jul 21;339(jul21 1):b2700-b2700 [FREE Full text] [doi: 10.1136/bmj.b2700] [Medline: 19622552]

235. Terwee CB, Prinsen CAC, Ricci Garotti MG, Suman A, de Vet HCW, Mokkink LB. The quality of systematic reviews of health-related outcome measurement instruments. Qual Life Res 2016 Apr 7;25(4):767-779 [FREE Full text] [doi:

10.1007/s11136-015-1122-4] [Medline: 26346986]

\section{Abbreviations}

ADDQoL-19: 19-item Audit of Diabetes-Dependent Quality of Life

CH-ASIQ: Chinese Attitudes to Starting Insulin Questionnaire

CIRS: Chronic Illness Resources Survey

C-ITAS-HK: Insulin Treatment Appraisal Scale in Hong Kong primary care patients

COSMIN: COnsensus-based Standards for the selection of health Measurement Instruments

C-PDQ: Chinese version of the Personal Diabetes Questionnaire

CUDOS-Chinese: Mandarin Chinese Version of the Clinically Useful Depression Outcome Scale

DAAS: Diabetes Adjustment Assessment Scale

DES-SF: Diabetes Empowerment Scale-Short Form 
DHPSC: diabetes health promotion self-care scale

DMKT: Diabetes Mellitus Knowledge Test

DMSES: diabetes management self-efficacy scale

DOQ: Diabetes Obstacles Questionnaire

DPMD: diabetes-specific measure of patient desire to participate in medical decision making

DQOL: Diabetes Quality-of-Life Measure

DRNK: diabetes-related nutrition knowledge questionnaire

DSMI-20: Diabetes Self-Management Instrument Short Form

DSMQ: Diabetes Self-management Questionnaire

DTSQ: Diabetes Treatment Satisfaction Questionnaire

ED-5Q: EuroQol 5-Dimension

FACIT: Functional Assessment of Chronic Illness Therapy

FH-15: new fear of hypoglycemia scale

GRADE: Grading of Recommendations Assessment, Development and Evaluation

HAPA: health action process approach

HCCQ-P: Persian Health Care Climate Questionnaire

HSQ 2.0: Health Status Questionnaire 2.0

KHLS-DM: Korean Health Literacy Scale for Diabetes Mellitus

MAT insulin: Measurement of Adherence to Drug Therapy in Diabetes Mellitus-Insulin Therapy

MAT OADS: Measurement of Adherence to Drug Therapy in Diabetes Mellitus-Oral Antidiabetics

PACIC: Patient Assessment of Chronic Illness Care

PAID: Problem Areas in Diabetes scale

PAID-5: short form of the Problem Areas in Diabetes scale

PCSD-P: Persian Version of Perceived Competence Scale for Diabetes

PHQ-9: Patient Health Questionnaire-9

PRISMA: Preferred Reporting Items for Systematic Review and Meta-Analysis

PRO-DM-Thai: instrument for patient-reported outcomes in Thai patients with type 2 diabetes mellitus

PROM: patient-reported outcome measure

T2DHPS: Type 2 Diabetes and Health Promotion Scale

WHOQOL-100: World Health Organization Quality of Life questionnaire

\author{
Edited by $R$ Kukafka; submitted 14.10.20; peer-reviewed by H Goh, Z Zrubka; comments to author 26.11.20; revised version received \\ 18.12.20; accepted 14.06.21; published 13.08.21 \\ Please cite as: \\ Wee PJL, Kwan YH, Loh DHF, Phang JK, Puar TH, Østbye T, Thumboo J, Yoon S, Low LL \\ Measurement Properties of Patient-Reported Outcome Measures for Diabetes: Systematic Review \\ J Med Internet Res 2021;23(8):e25002 \\ URL: https://www.jmir.org/2021/8/e25002 \\ doi: $10.2196 / 25002$ \\ PMID:
}

(CPriscilla Jia Ling Wee, Yu Heng Kwan, Dionne Hui Fang Loh, Jie Kie Phang, Troy H Puar, Truls Østbye, Julian Thumboo, Sungwon Yoon, Lian Leng Low. Originally published in the Journal of Medical Internet Research (https://www.jmir.org), 13.08.2021. This is an open-access article distributed under the terms of the Creative Commons Attribution License (https://creativecommons.org/licenses/by/4.0/), which permits unrestricted use, distribution, and reproduction in any medium, provided the original work, first published in the Journal of Medical Internet Research, is properly cited. The complete bibliographic information, a link to the original publication on https://www.jmir.org/, as well as this copyright and license information must be included. 